\title{
Evaluation of the performance gap in industrial, residential \& tertiary near-Zero energy buildings
}

\author{
N. Kampelis ${ }^{\mathrm{a}, *}$, K. Gobakis ${ }^{\mathrm{a}}$, V. Vagias ${ }^{\mathrm{a}}$, D. Kolokotsa ${ }^{\mathrm{a}}$, L. Standardi ${ }^{\mathrm{b}}$, D. Isidori ${ }^{\mathrm{b}}$, \\ C. Cristalli ${ }^{b}$, F.M. Montagnino ${ }^{c, d}$, F. Paredes ${ }^{c, d}$, P. Muratore $^{c}$, L. Venezia $^{c}$, \\ M. Kyprianou Dracou ${ }^{e}$, A. Montenon ${ }^{e}$, A. Pyrgou $^{e}$, Theoni Karlessi ${ }^{f}$, Mat Santamouris ${ }^{f}$ \\ a Energy Management in the Built Environment Research Lab, Environmental Engineering School, Technical University of Crete, Technical University \\ Campus, Kounoupidiana, GR 73100 Chania, Greece \\ ${ }^{\mathrm{b}}$ Research for Innovation, AEA srl, via Fiume 16 60030, Angeli di Rosora (AN), Italy \\ ${ }^{c}$ IDEA srl, C.da Molara, Z.I. III Fase, I 90018, Termini Imerese, Italy \\ d Consorzio ARCA, Viale delle Scienze, Building 16, I 90128, Palermo, Italy \\ e The Cyprus Institute, 20 Constantinou Kavafi Street, Nicosia 2121, Cyprus \\ ${ }^{\mathrm{f}}$ National and Kapodistrian University of Athens, Department of Physics, Athens, Greece
}

\section{A R T I C L E I N F O}

\section{Article history:}

Received 28 December 2016

Received in revised form 7 March 2017

Accepted 24 March 2017

Available online 30 March 2017

\section{Keywords:}

Smart buildings

Performance gap

Near-Zero Energy Building (NZEB)

\begin{abstract}
A B S T R A C T
Energy efficiency, advanced controls and renewable energy systems for operating industrial, residential and tertiary sector buildings designed to be Near-Zero Energy are investigated to explore the performance gap. The analysis involves a comparison of energy dynamic and quasi-dynamic models with data from smart monitoring systems, indoor and outdoor environment measurements, power consumption and production data. Specific issues and conclusions have been drawn as the basis for addressing the performance gap between energy efficiency prediction in the design phase and measurements' evaluation in operational phase.
\end{abstract}

(C) 2017 Elsevier B.V. All rights reserved.

\section{Introduction}

The concept of Smart and Zero Energy Buildings has attracted the interest of the scientific community, policy organisations and the industry worldwide. In particular, special attention is paid to bridge integrated design and energy efficiency in new and renovated buildings via strategic energy and environmental objectives, policy initiatives, regulatory reforms and financial incentives. The EU has placed a particular emphasis on the reduction of the high energy consumption in the building sector within various policy tools and directives including the EU 2020 targets, the Energy Performance Building Directive (EPBD), the climate change adaptation and mitigation strategies and the low carbon economy roadmap $2050[1,2]$.

EPBD Recast (2010), needs to be fully adopted by each member state to ensure all public buildings (or buildings used by public organisations) as well as new buildings comply with near-zero energy consumption by 2018 and 2020 respectively. Under the

\footnotetext{
* Corresponding author.

E-mail address: nkampelis@isc.tuc.gr (N. Kampelis).
}

agreed legislative framework, Member States are responsible to report on the detailed application of Near-Zero Energy Buildings (NZEBs) requirements in practice reflecting national, regional or local conditions.

The EPBD NZEB definition for a very high energy performance, a very low amount of required energy and a very significant contribution of RES to cover the remaining energy use provides the conceptual basis for our analysis. A very high energy performance is translated into the building incorporating passive and active systems design, attaining a better performance than national minimum energy efficiency requirements and fall into the top categories of the energy certification process.

However a clear universal definition of a Zero Energy Building is somewhat of a challenge and usually linked to the framework of the analysis whether this is carried out for construction design, energy efficiency classification, specific research, policy tools development or other purposes. Definitions may vary according to the metric and period of balance, type of energy use and balance, renewable supply options, connection with power network, requirements, etc. [3]. Apart EPBD, linked to annual normalised primary energy consumption (in $\mathrm{kWh} / \mathrm{m}^{2} / \mathrm{year}$ ), various definitions have been proposed including net zero site energy, net zero source energy, net 
zero energy costs and net zero energy emissions depending on the selected metric (energy, cost, $\mathrm{CO}_{2}$ emissions) and domain (site or source). Where applicable, a net-zero site energy benchmark is considered most appropriate as it is verifiable through on-site measurements and cannot be affected by external factors (i.e. related to the power grid or the energy market) which may differ between design and operation phases as well as from one site (or country) to another.

In our analysis, a combination of metrics including primary energy consumption and end-use net consumption (absolute and normalised figures) as well as $\mathrm{CO}_{2 \text {-eq }}$ emissions is deployed. The period of balance is annual to account for yearly representative thermal loads and renewable energy production. Renewable supply in all three considered cases is on-site and building integrated. Of the examined cases, the residential and tertiary buildings are directly connected to the power distribution grid directly and the industrial one as part of a microgrid.

Regarding quantitative targets linked to the zero or near-zero energy target, it is noteworthy that based on indicative studies they are dispersed from 0 to $270 \mathrm{kWh} / \mathrm{m}^{2} /$ year of primary energy consumption of which higher figures are associated with hospitals or non-residential buildings [4]. For NZE residential buildings the average targets are from $33 \mathrm{kWh} / \mathrm{m}^{2} /$ year in Croatia, $95 \mathrm{kWh} / \mathrm{m}^{2} /$ year and $45-50 \mathrm{kWh} / \mathrm{m}^{2} /$ year for the majority of countries (Belgium, Estonia, France, Ireland) while some countries use non-dimensional values or an energy performance class (e.g. A++ in Lithuania) [5]. In Italy, the regulation for new dwellings requires a minimum energy efficiency of $65-70 \mathrm{kWh} / \mathrm{m}^{2}$ [6]. In Cyprus, the threshold for NZEB is $100 \mathrm{kWh} / \mathrm{m}^{2} /$ year of primary energy for new and existing residential buildings and $125 \mathrm{kWh} / \mathrm{m}^{2} /$ year of primary energy for non-residential buildings [4].

On the other hand, ZEB or NZEB currently in operation or even those in development stages make use of energy efficient technologies with fossil fuel as primary energy sources coupled with renewables such as solar, wind, geothermal or biomass to attain "nearly-zero energy" behaviour [5,7]. The transition to smart ZEBs from an engineering or industrial point of view depends partially on the development of standardized interfaces and exploitation of common communication protocols to enable interoperability of systems and subsystems as well as adequate bi-directional flow of energy and information [8]. Coupling existing building energy systems with modern monitoring and control equipment is often another barrier for renovating the existing building stock.

Discussions in this direction expand towards issues related to the integration of NZE buildings in smart grids with the aid of evolving technologies $[9,10]$. Various efforts have dealt with optimising the design and operation of building integrated renewables, thermal or electrical storage and holistic energy management using a broad range of techniques. Attention has been drawn in developing tools for user/customer engagement and transparency of grid operations with the aid of Advanced Monitoring Infrastructure (AMI) and Demand Response (DR) capabilities to make a step closer to the Internet of Things (IoT) paradigm [11].

In many occasions, significant deviations of buildings' overall energy efficiency target compared to its actual operating performance have been reported. The 'performance gap' is associated to a number of contributing factors in the design and construction of the building envelope and systems or in the management procedures affecting the operational phase of the building. In the design phase the performance gap is often related to the misuse of calculation methodologies and tools or input parameters. In other cases, the performance gap is linked to the lack of consideration and deployment of Integrated Design (ID) principles impacting energy consumption, indoor comfort and health conditions. Performance gap issues are also evident during the construction phase and improper installation of building envelope components (i.e. insulation, glazing etc.) as a result of inadequate training, costcutting constraints or barriers related with resistance to change $[12,13]$. Such phenomena may have as a consequence the occurrence of thermal bridges, high infiltration rates, and poor indoor comfort eventually leading to energy waste and high total energy consumption. Last but not least, energy management and operational inefficiencies are critical to the observed gap in buildings' energy performance in buildings, depending on the specificities of each case. This may be due to lack of maintenance and service, misuse of energy systems' operation or suboptimum performance in systems' integration. Overall, there is a high potential for improvements in bridging the 'gap' due to underperformance in operational phase and this can in most cases be effectively addressed via a mixture of technological and organisational measures.

In terms of the technological measures, indoor environment quality control and Building Energy Management Systems (BEMS) have evolved considerably in the last decades, in parallel with the concept of Smart and Near-Zero Energy Buildings. Advanced BEMS can be implemented in ways altering the way buildings exchange energy with the ambient environment and the power grid. At the same time modern customised building energy management solutions, can be exploited to enable better visual, thermal comfort and air quality control. Furthermore, BEMS nowadays offer possibilities for applying predictive control which may contribute to $20-30 \%$ in annual energy consumption reduction [14-16] but also significant operational cost savings. Energy load prediction is becoming increasingly important and promising as a cost effective measure in the near future $[14,15]$. Simultaneously, intensive research is focused on renewable energy production prediction to increase utilisability in building integrated applications and deal with the volatility of Decentralised Energy Resources (DER) and the future microgrids.

Furthermore, data processing and smart metering interpretation provide useful information for the buildings energy behaviour [17]. This process is especially important when such knowledge can be acquired to inform decisions about systems' operational strategies based on scientifically sound and technologically robust methodologies. In this direction, Demand Response (DR) techniques have been applied in various settings to optimise the operation of building energy systems (i.e. HVAC) and yield financial return based on the minimisation of energy from the power grid and load management $[18,19]$. Accordingly, data monitoring, the provision of meaningful information and practical tools combined with specific incentives provide the fundamentals for actively engaging users in realising the potential of DR wide scale environmental and social benefits. This transition requires action for training users and establishing a transparent, open and attractive regulatory framework followed by targeted investments both on power grid infrastructure and on the end users' side.

With respect to renewables, advanced solutions such as concentrating solar thermal technologies have emerged to offer attractive options in meeting the cooling demand during the summer season and in part heating demand during winter time. The real challenge with such systems concerns the design of a suitable and efficient solution utilizing maximum heat from the sun to fulfill the required energy demand [20].

Other commercially available solutions include buildingintegrated Photovoltaics (biPV) and small wind turbine systems offering a broad range of designs and technical attributes. Such systems are coupled with inverters often equipped with Maximum Power Point Tracking (MPPT) and controls for providing energy into the power grid, microgrid or autonomous systems [21-23]. Recently, building integrated combined Solar and Wind driven energy systems have penetrated the market promising to be a cost viable breakthrough technology. 
This work aims to propose a comprehensive approach for evaluating the performance of various Smart/Near-Zero Energy buildings including industrial, residential and tertiary case studies. Initially, the buildings are audited for a detailed analysis of their construction, systems installed and operational performance as originally designed and predicted. Subsequently, holistic data from advanced metering and sensor equipment is explored for verifying energy demand and actual performance. Dynamic and quasi-dynamic energy models are developed and exploited to explore key aspects of the operational behaviour of buildings and systems and draw essential knowledge about potential improvements.

The second section of this paper refers to the materials and methods used for the evaluation of the performance gap in the selected test cases. Chapter 3, 4 and 5 present the case studies of the Leaf Lab, Leaf House and NTL respectively and the analytic comparison of their design and operational performance using key performance indicators. A consideration of results and benchmarking of the different tools and techniques is provided in Chapter 6 . Finally, generic conclusions associated with the operational 'performance gap' of the buildings examined and future steps are highlighted in chapter 7 .

\section{Materials and methods}

The research activities performed and presented target to the estimation and evaluation of the performance gap between the design and operational phase of zero energy buildings. The steps followed are:

1. Selection of the case study buildings: Three case studies are analysed to cover industrial, residential and office building typology. The Leaf Lab, Leaf House and Novel Technologies Laboratory (NTL) envisage unique building designs for minimizing net energy consumption. This is achieved through a variety of measures including responsive building envelope applications, renovated bioclimatic envelope, efficient HVAC systems coupled with storage, intelligent controls, renewable energy systems and integrated energy management. The buildings' names and implemented energy technologies are depicted in Table 1 . The design target of all three buildings to operate as near-zero energy is established as a working definition to evaluate the actual performance gap.

2. The second step involves analysis of the buildings and their systems design, assessment of power and energy requirements through dynamic thermal simulation models.

3. The third step is the data collection while the buildings are in real-time operation to test and evaluate:

a The performance gap between the developed dynamic simulation models and real-time operation.

b The performance gap between the initial zero energy targets and buildings' real-time operation.

4. The fourth step includes a comparison of the results of the buildings and extraction of useful remarks and conclusions.

\section{The Leaf Lab industrial building, AEA Italy}

\subsection{Description of the building and its energy technologies}

The Leaf Lab (Fig. 1) is an industrial building of rectangular shape and floor area of approximately $6000 \mathrm{~m}^{2}$ located in the Leaf Community [24], one of the very well established smart microgrids in Europe. Buildings in the Leaf Community, located in Angeli di Rosora of Ancona in Italy, are interconnected with Photovoltaic (PV), Geothermal Systems, electric and thermal storage, microhydroelectric plants and electric vehicles (EV). The climate in

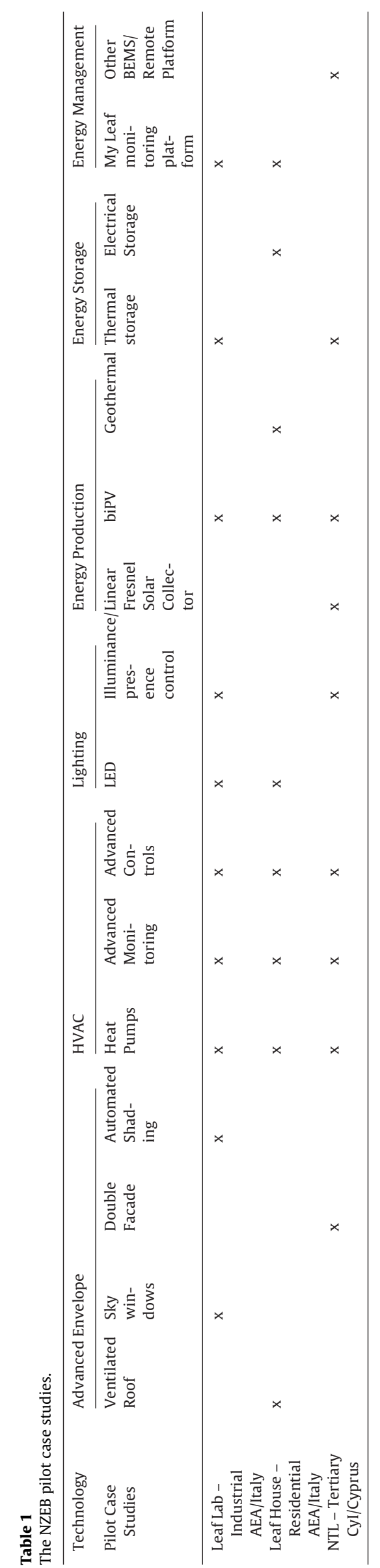




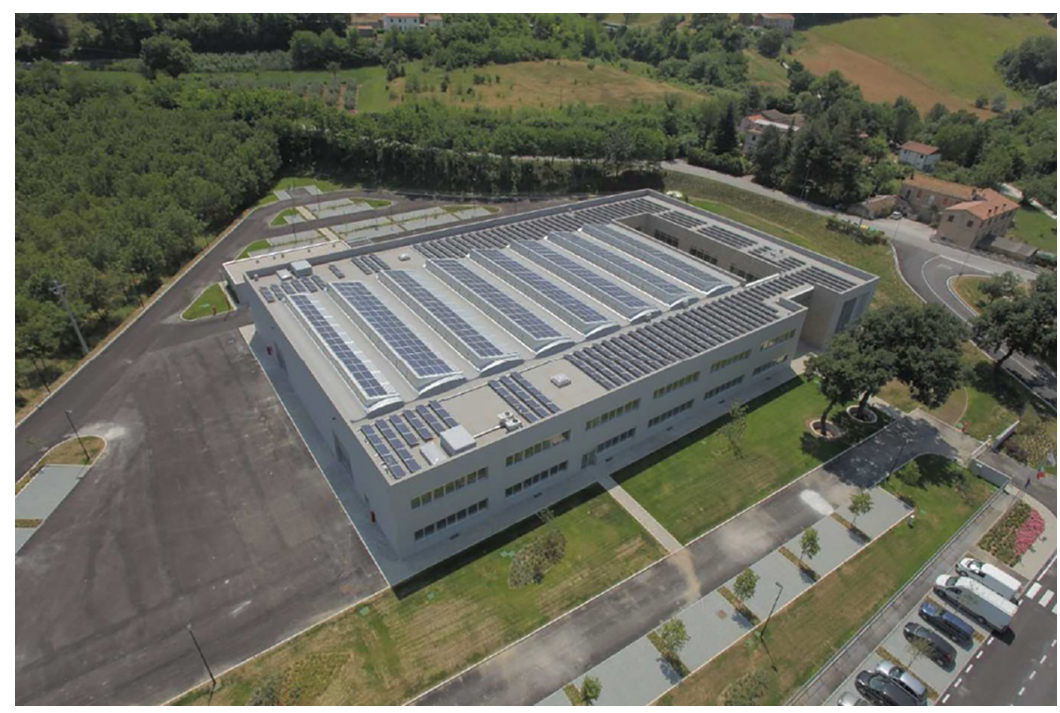

Fig. 1. The Leaf Lab.

Ancona is mediterranean with dry hot summers and mild winters. Warm season starts in June and lasts till mid-September with an average high temperature of $29^{\circ} \mathrm{C}$ and average low temperature of $19^{\circ} \mathrm{C}$. Cold season starts in November and ends in March with average high temperature below $12^{\circ} \mathrm{C}$ [25].

The Leaf Lab incorporates the newest technology making it exceptionally tolerant to external weather conditions. This reduces to the minimum the amount of energy needed to cover the energy demand for heating, cooling, ventilation and lighting. The Leaf Lab is considered a Near-Zero Energy Building since it is characterized by passive systems, energy efficient technologies, integrated monitoring and control as well as renewable energy production. Renewable energy is exploited with the use of PV systems and heat pumps. Thermal storage is also employed to store energy and optimize HVAC performance.

The building envelope of Leaf Lab consists of highly insulated external walls with U-value of $0.226 \mathrm{~W} / \mathrm{m}^{2} \mathrm{~K}$ and double glazed windows with U-value between $1.793-3.194 \mathrm{~W} / \mathrm{m}^{2} \mathrm{~K}$. The HVAC system installed in Leaf Lab is comprised by heat pumps with a heating COP of 4.8 and cooling EER of 6.2-7. A thermal storage water tank of $400 \mathrm{~m}^{3}$ is coupled to the HVAC system of the building to reduce peak power and improve the efficiency of the HVAC system during heating and cooling periods throughout the year. This is implemented by using energy excess from the PV i.e. during weekends, holidays etc. to operate the heat pumps and store heating or cooling energy in the thermal tank. Stored energy is then used to optimise the HVAC efficiency by reducing peak demand and imported energy consumption during working hours. The HVAC is controlled with digital thermostats distributed in the various thermal zones satisfying the set-point limits of the CEN 15251 (20-24 ${ }^{\circ} \mathrm{C}$ for heating, $23-26^{\circ} \mathrm{C}$ for cooling). Set-points for industrial and office spaces in heating mode are $21^{\circ} \mathrm{C}$ and $22^{\circ} \mathrm{C}$ whereas in cooling more set points are $25^{\circ} \mathrm{C}$ and $26^{\circ} \mathrm{C}$ respectively.

Illuminance sensors controlling artificial lighting in the indoor spaces of the Leaf Lab activate dimmable LED lights when levels due to natural lighting fall below $500 \mathrm{~lx}$.

Furthermore, automated shading is installed in the majority of the building windows and operated according to the altitude of the sun. This allows for natural light to be sufficient for visual comfort while minimising energy consumption for artificial lighting and avoiding glare. Finally, as shown in Fig. 1 a rooftop photovoltaic system of $236.5 \mathrm{kWp}$ is installed in Leaf Lab.

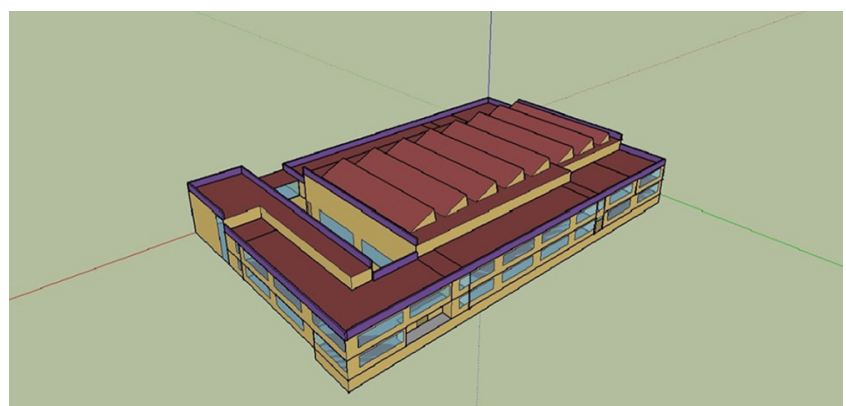

Fig. 2. The thermal model of the Leaf Lab in Google SketchUp.

The energy efficiency of the Leaf Lab as recorded in the energy certificate was $\mathrm{A}+$ associated with net primary energy consumption of $4.11 \mathrm{kWh} / \mathrm{m}^{3}$ (equivalent to $26.91 \mathrm{kWh} / \mathrm{m}^{2}$ ).

\subsection{Development of the Leaf Lab thermal model}

The aim of the present section is to analyse Leaf Lab' energy performance and compare modelling results with real-time data. Modeling and analysis for the Leaf Lab is carried out using Google SketchUp [26] as graphical user interface for 3D modelling, Open Studio [27] for editing the various model parameters and EnergyPlus [28] as the simulation engine. The model is depicted in Fig. 2. Architectural drawings are used to design the structure's envelope and merge the several spaces into thermal zones. Electromechanical and implemented HVAC system designs are taken into consideration. Moreover, the physical and thermal characteristics of the external and internal walls, roof, ground floor and ceiling, alongside with similar information about the external windows are collected. The lights of each space, total number of persons in each space as well as equipment information are recorded for the estimation of the internal thermal gains and electrical energy consumption.

\subsection{Energy performance analysis}

In order to test the performance differences, data is collected, analysed and processed. The validation of the model is then performed using temperature and relative humidity sensors installed in the various zones. Additional data is extracted by MyLeaf [29], a 


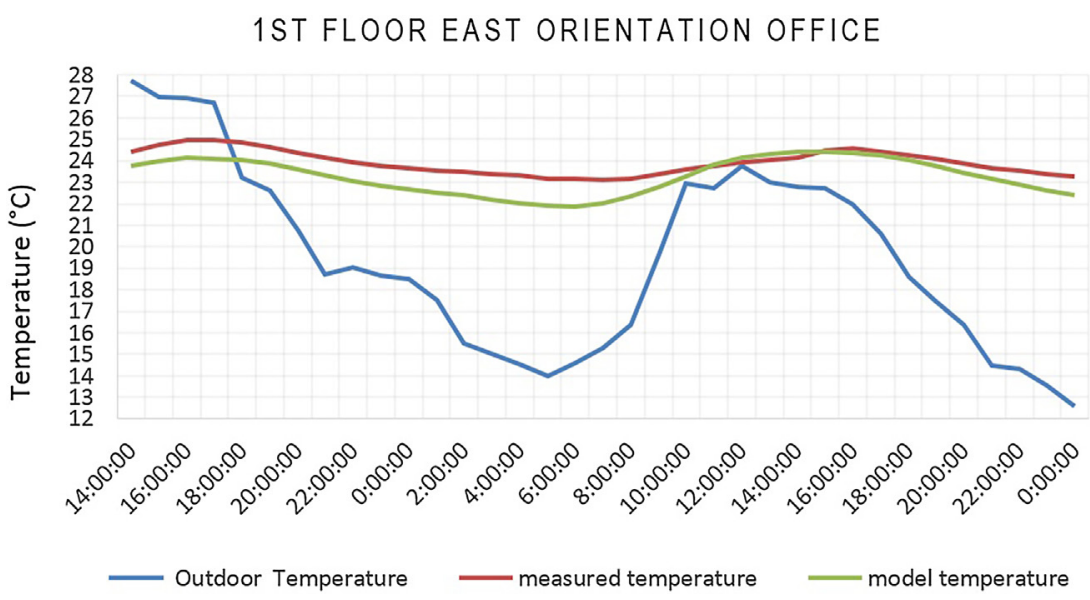

Fig. 3. 1st Floor East Office measured and simulated indoor temperature.

\section{GROUND FLOOR RECEPTION}

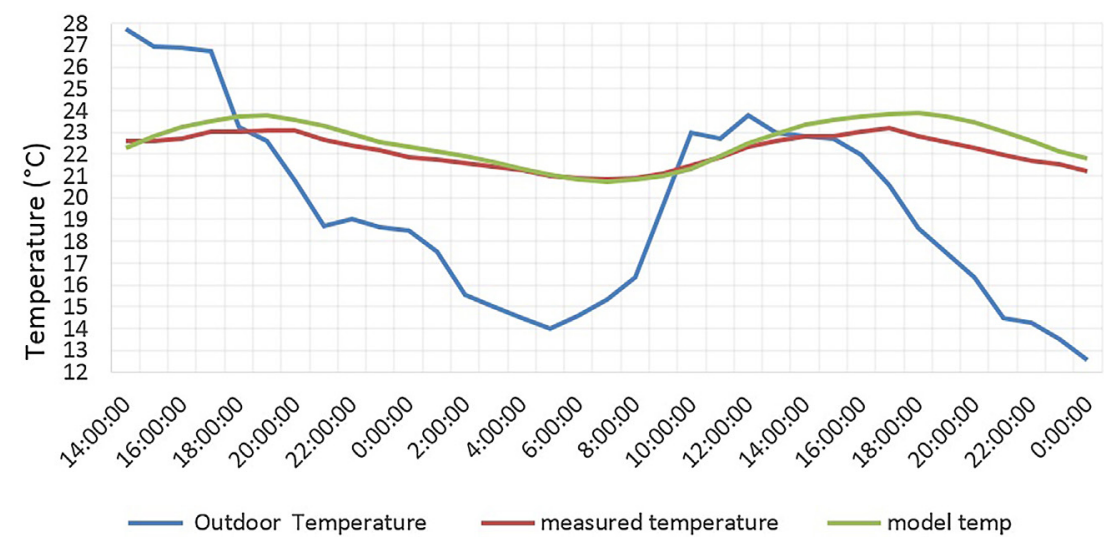

Fig. 4. Ground floor, Leaf Lab reception measured and simulated indoor temperature.

specialised Loccioni Group proprietary web-based Energy Management System, providing reliable and user-friendly representation of any energy related monitored parameter such as ambient and indoor environment conditions, power consumption, production and storage over time. The open MyLeaf architecture allows the integration of advanced energy management and control applications in building and microgrid (district) level.

Specifically, the collected data from MyLeaf is: (a) Building total and HVAC power demand and (b) power production by the photovoltaic system.

As it can be observed in Figs. 3 and 4, the simulated indoor temperature versus the measured one is less than $1 \mathrm{~K}$ at all times. The same applies to the Reception area as well as all the rooms monitored indicating agreement between the simulated and measured data.

A comparison of the measured and simulated energy consumption is tabulated in Table 2. It is observed that the difference in energy consumption between the various categories is of $1.4 \%$ for artificial lighting, $0.6 \%$ for HVAC, $0.4 \%$ for equipment (including industrial processes) and $0.1 \%$ in total which provides a positive correlation between simulation results and the actual behaviour of the building during its operational phase.

As indicated the energy share consumed in the production of this industrial facility is the highest between the categories accounting for $53.1 \%$. This is of particular importance when one considers the energy balance (especially given the PV electrical energy production of $46 \mathrm{kWh} / \mathrm{m}^{2}$ ) as it reveals the building envelope, HVAC and lighting systems electrical energy consumption of $43.8 \mathrm{kWh} / \mathrm{m}^{2}$. For the conversion of electrical energy to primary energy consumption, a factor of 1.86 is used based on internationally reported estimation for the energy mix distribution and power grid efficiency of Italy [31]. Taking into account energy production from the PV plant it is concluded that the Leaf Lab is a Near-zero Energy Industrial Building with total net electrical energy consumption of $47.3 \mathrm{kWh} / \mathrm{m}^{2}$ and normalized total net primary energy consumption of $127.6 \mathrm{kWh} / \mathrm{m}^{2}$.

The correlation of the Leaf Lab model and the measured HVAC power demand on a monthly basis as presented in Fig. 5 demonstrates part of the validation process according to standardized measurement and verification principles [30]. In the examined case, the Coefficient of Variation (CV) of the Root Mean Square Error (RMSE) of $14.8 \%$ satisfies acceptable monthly tolerance levels.

\section{Leaf House residential building AEA/Italy}

\subsection{Description of the building and its energy technologies}

The Leaf House (Fig. 6) is a residential rectangular geometry apartment building of exceptional bioclimatic design and smart technologies [32]. It consists of six highly insulated apartments with a total floor area of approximately $470 \mathrm{~m}^{2}$, a ventilated roof, solar tubes, smart monitoring, and controls, building integrated photovoltaics, geothermal air preconditioning with heat pumps, 
Table 2

Validation of the Leaf Lab Model based on data from MyLeaf.

\begin{tabular}{|c|c|c|c|c|c|}
\hline Leaf Lab (Industrial) & & Artificial Lighting & HVAC & Industrial/Office Equipment & Total \\
\hline \multirow{6}{*}{ Monitored data } & Electrical Energy Consumption (kWh) & $35,467.3$ & $227,176.1$ & $297,366.1$ & $560,009.5$ \\
\hline & Normalised Electrical Energy Consumption $\left(\mathrm{kWh} / \mathrm{m}^{2}\right)$ & 5.9 & 37.9 & 49.6 & 93.3 \\
\hline & Energy Consumption (\%) & $6.3 \%$ & $40.6 \%$ & $53.1 \%$ & $100.00 \%$ \\
\hline & Normalised Primary Energy Consumption $\left(\mathrm{kWh} / \mathrm{m}^{2}\right)$ & 11.0 & 70.4 & 92.2 & 173.6 \\
\hline & Energy Production by the PV (kWh) & & & & 275,942 \\
\hline & Normalised PV energy $\left(\mathrm{kWh} / \mathrm{m}^{2}\right)$ & & & & 46 \\
\hline \multirow[t]{3}{*}{ Simulated data } & Energy Consumption (kWh) & $34,985.5$ & $225,838.3$ & $298,604.2$ & $559,428.0$ \\
\hline & Normalised Electrical Energy Consumption $\left(\mathrm{kWh} / \mathrm{m}^{2}\right)$ & 5.8 & 37.6 & 49.8 & 93.2 \\
\hline & Energy Consumption (\%) & $6.3 \%$ & $40.4 \%$ & $53.4 \%$ & $100.0 \%$ \\
\hline \multirow[t]{2}{*}{ Difference } & Energy Consumption (kWh) & 481.8 & 1337.8 & -1238.1 & 581.5 \\
\hline & Energy Consumption (\%) & $1.4 \%$ & $0.6 \%$ & $0.4 \%$ & $0.1 \%$ \\
\hline
\end{tabular}

\section{Model / Measured (MyLeaf) HVAC Electric Consumption}

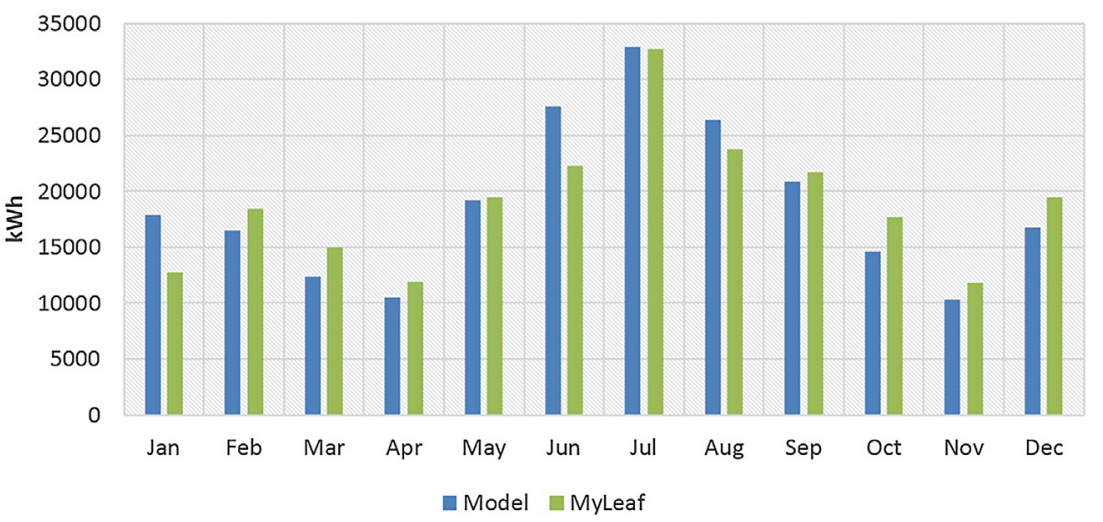

Fig. 5. HVAC system validation based on monthly electrical energy consumption.

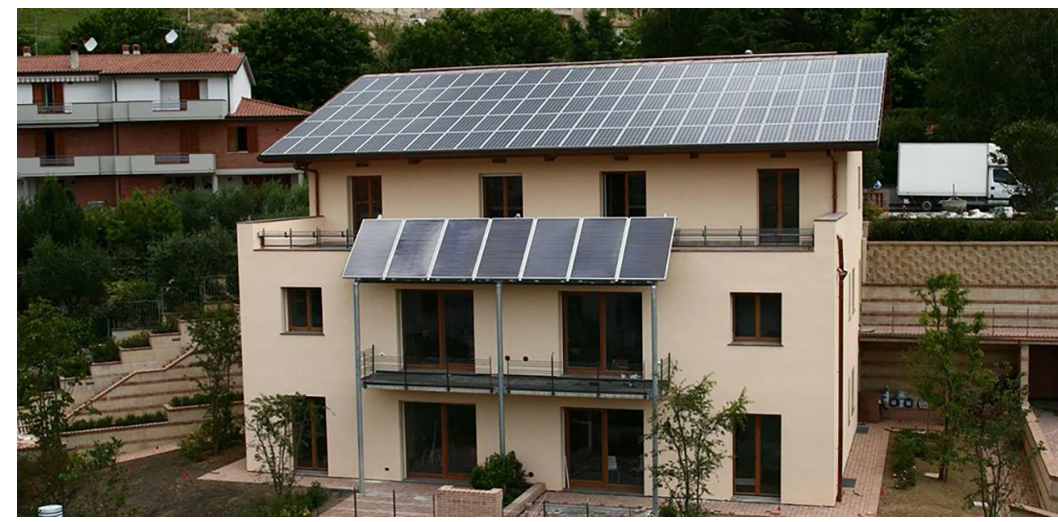

Fig. 6. The Leaf House.

solar thermal collectors, electrical storage and a user-friendly energy management system for residents. The number of residents in Leaf House varies as it accommodates both employees of Loccioni Group [33] and visitors of the Leaf Community [34].

The building envelope of Leaf House is composed of external walls with a U-value of $0.41 \mathrm{~W} / \mathrm{m}^{2} \mathrm{~K}$ and windows of total $\mathrm{U}$ value between $0.73-1.49 \mathrm{~W} / \mathrm{m}^{2} \mathrm{~K}$. The HVAC System installed in Leaf House is comprised of three heat pumps with geothermal air preconditioning and heat recovery connected to a radiant floor distribution system. The heating COP of the heat pumps is in the range from 2.9 to 4.6 while the cooling EER varies between 1.9 to 3.6.
Seven solar thermal collectors of a total area of $19 \mathrm{~m}^{2}$ are connected to a 10001 thermal storage boiler of $15 \mathrm{~kW}$ electrical power for domestic hot water and space heating.

Moreover, a $20 \mathrm{kWp}$ PV system is integrated into the Leaf House's rooftop as depicted in Fig. 6. Energy produced by the photovoltaic system is mainly exploited to power the geothermal heat pumps and reduce overall power consumption. To accomplish this, 115 PV panels covering a total area of $150 \mathrm{~m}^{2}$ are installed.

According to the energy certificate of the Leaf House its normalised annual primary energy consumption is $19.66 \mathrm{kWh} / \mathrm{m}^{2}$ corresponding to A+ energy class.

The apartments in the Leaf House are equipped with a touch display providing access to an energy management interface for 


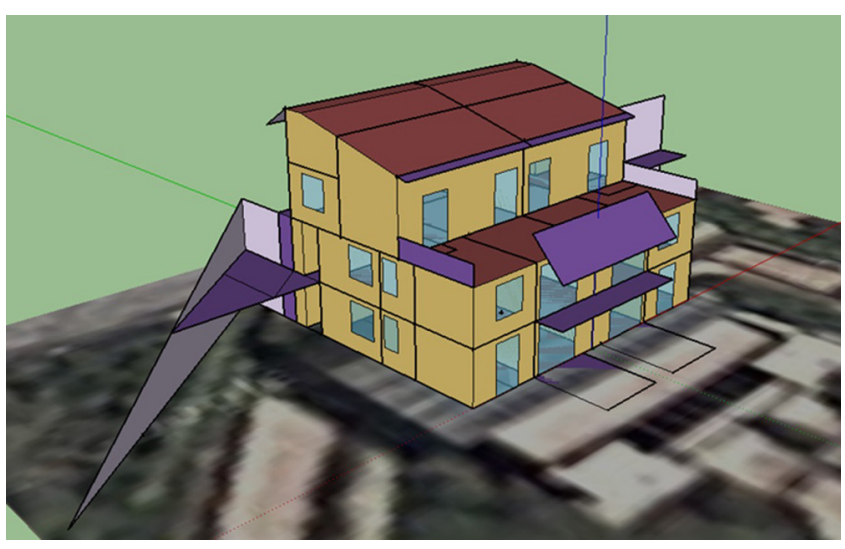

Fig. 7. The Leaf house and its thermal energy model using Open Studio plugin.

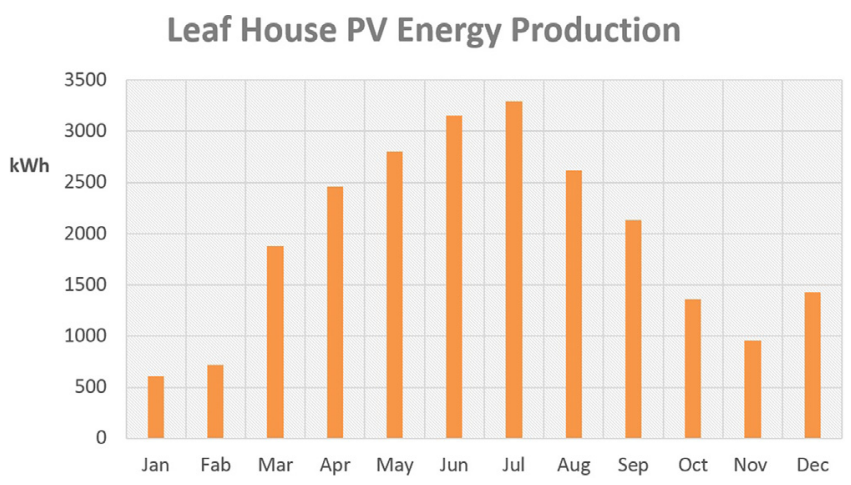

Fig. 8. Leaf House PV System Monthly Energy Production for 2015 (MyLeaf).

observing indoor conditions, energy-related data and managing automatic controls of HVAC, lights, window shutters etc. Also, power measurements for each apartment in the Leaf House are accessible through MyLeaf platform.

\subsection{Development of Leaf House thermal model}

Modeling and analysis of the Leaf House as in the case of Leaf Lab is carried out using Google SketchUp [26] as graphical user interface for 3D modelling, Open Studio [27] for editing the various model parameters and EnergyPlus [28] as simulation engine. The developed 3D model is depicted in Fig. 7. The thermal zone division is performed with a large attention to detail having, as a result, every room being considered a separate thermal zone to best capture differences in indoor comfort.

Energy performance in Leaf House according to 2015 data from MyLeaf is summarized in Table 3. In the measurements, it is observed that Leaf House is a Near-Zero Energy Building since its normalized primary energy consumption is $54.4 \mathrm{kWh} / \mathrm{m}^{2}$. The PV system energy production accounts for $63.1 \%$ of the building energy demand and $\mathrm{CO}_{2-\text { eq }}$ emissions reduction of $11.32 \mathrm{t}$ on a yearly basis (Fig. 8).

\section{Novel Technologies Laboratory (NTL) building}

Cyprus is characterised by a mediterranean climate with dry hot summers and mild winters. During the year the temperature normally varies between 5 and $32^{\circ} \mathrm{C}$ with the warm season from mid-May to mid-September and the cold season from beginning of November and lasts till mid-March [35]. The energy system in Cyprus is seriously impacted by the growing demand of energy in the summertime due to the air conditioning services [36]. This sit-

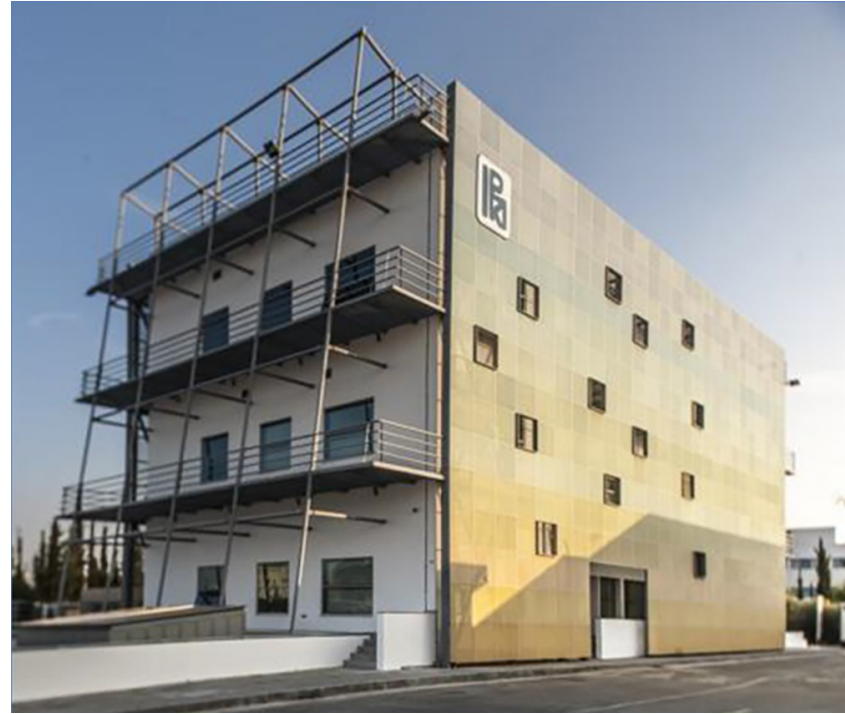

Fig. 9. NTL building.

uation is very common to all the south Mediterranean regions as well other areas with a high level of solar irradiance.

Indeed, global space cooling energy consumption increased by $60 \%$ in the period between 2000 and 2010 reaching $4 \%$ of global consumption in 2010 and it is still growing [37]. On the other hand heat consumption accounts for more than $50 \%$ of the global consumption [38]. Therefore, alternative heating and cooling systems driven by renewable or recovered energy have driven the interest of many researchers that have carried out experimental and theoretical studies of Solar Heating Cooling (SHC) systems [39-44]. Absorption heating and cooling systems were studied more than any other systems. These systems have many advantages over other refrigeration systems [35] as they offer quiet operation, high reliability, long service life, meeting the variable load efficiently, minimum mechanical moving parts, no lubricants needed and no atmosphere-damaging refrigerants. Dynamic simulation is performed by many researchers [45-48], but there is still a lack of integrated tools for accurate dimensioning and evaluating the solar thermal contribution to the total energy requirements. Also theoretical comparative studies between different solar cooling systems (i.e. solar electrical compression, solar mechanical compression, solar absorption, solar adsorption and solid desiccant cooling system) [49] are available. The results show that solar electrical compression alongside solar absorption systems may have better performance results. Moreover, the advantages of two-stage systems over other solutions have been investigated [50], concluding that the cooling cycle can work steadily in spite of unsteady solar input, lower generator input and outlet temperature, however, they demand higher temperature heat.

The National Technologies Laboratory (NTL) (Fig. 9) of Cyprus Institute is a top-end renovated tertiary building, which incorporates energy efficient technologies and integrates modern HVAC technology with a rooftop Linear Fresnel Solar Collector (Fig. 10), significantly reducing energy demand from the power grid. The installation of the new solar cooling plant at the NTL premises has been supported by the STS-Med project ${ }^{1}$ financed by the ENPI CBCMED program of the European Union, where it has been part of a constellation of 4 pilot plants which should demonstrate the potential application of solar energy in built environment, with a deep integration with the demand of energy raised by the neighborhood. 
Table 3

Leaf House energy consumption data for 2015 (MyLeaf).

\begin{tabular}{|c|c|c|}
\hline Leaf House & Total & Total Net(consumption minus production) \\
\hline Annual Electrical Energy Consumption (kWh) & $37,196.0$ & $13,746.0$ \\
\hline Normalized Annual Electrical Energy Consumption $\left(\mathrm{kWh} / \mathrm{m}^{2}\right)$ & 79.1 & 29.2 \\
\hline Primary Annual Energy Consumption (kWh) & $69,184.6$ & $25,567.6$ \\
\hline Normalized Annual Primary Energy Consumption $\left(\mathrm{kWh} / \mathrm{m}^{2}\right)$ & 147.2 & 54.4 \\
\hline Annual $\mathrm{CO}_{2-\mathrm{eq}}$ emissions $(\mathrm{kg})$ & 17965.7 & 6639.3 \\
\hline
\end{tabular}

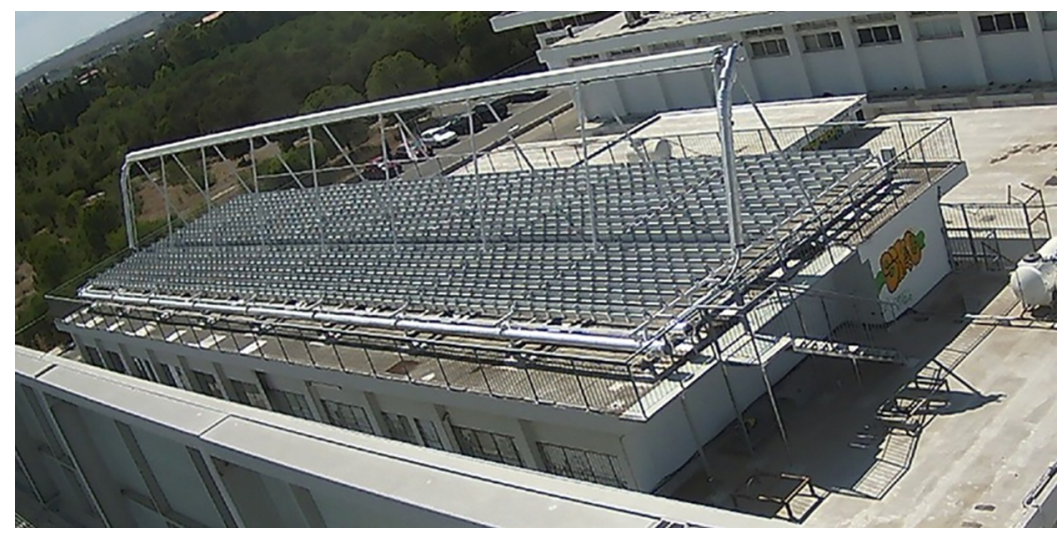

Fig. 10. Linear Fresnel Solar Collector.

The building was renovated in 2007 with a target to minimise consumption for heating and cooling and produce part of its electrical needs from a building integrated PV system. The baseline scenario concerned heating and cooling loads of $61.2 \mathrm{kWh} / \mathrm{m}^{2}$ and $78.3 \mathrm{kWh} / \mathrm{m}^{2}$ respectively. The design of interventions was based on simulations used to test various effects such as heat losses, solar gains, ventilation (free/night cooling, demand control) and daylight availability taking into account external shading constructions. The various interventions proposed during initial design were double glazing, high thermal resistance building envelope, green roof $(50 \%$ coverage), shading, ceiling fans, high efficiency waste heat recovery ventilation and ground heat exchangers. At the design stage it was considered that the above measures would result in $83 \%$ and $61 \%$ reduction of heating and cooling loads translated to $10.7 \mathrm{kWh} / \mathrm{m}^{2}$ and $30.2 \mathrm{kWh} / \mathrm{m}^{2}$ respectively. The above figures were obtained on the basis of international standards (EN 15251) for indoor comfort including fresh air ventilation rate, indoor temperature, indoor relative humidity and illuminance levels. The equivalent primary energy consumption for heating and cooling is $28.9 \mathrm{kWh} / \mathrm{m}^{2}$ and $81.54 \mathrm{kWh} / \mathrm{m}^{2}$ respectively [51]. Moreover it was estimated that the energy balance could further be improved by the installation of a PV in an area of $120 \mathrm{~m}^{2}$ to produce $21 \mathrm{MWh}\left(9.58 \mathrm{kWh} / \mathrm{m}^{2}\right)$ on a yearly basis.

Novel Technologies Laboratory is an educational/research building mainly containing offices and laboratories. The Novel Technologies Laboratory operates $8 \mathrm{~h} /$ day, Monday to Friday and for about 240 days/year. Cooling and heating of the building are provided by three air-cooled chillers with partial heat recovery connected to Fan Coil Units (FCU) in office areas and Air Handling Units (AHU) in laboratories and lecture hall. Two of them are cooling only with a capacity of $243.27 \mathrm{~kW}$ with $\mathrm{EER}=2.35$, ESEER $=4.17$, while the other one has a cooling capacity of $234.29 \mathrm{~kW}$ with EER $=2.24$ and ESEER = 3.97 and a heating capacity of $293 \mathrm{~kW}$ with COP $=3.15$.

Ventilation at offices is achieved with local heat recovery units (HRU), at the lecture hall and laboratories with AHU and the WC areas with local extract fans. The six AHU are supplied with hot and cold water, generated by the 2 chillers and the heat pumps. Each unit has a heat recovery unit where indoor air and fresh air are mixed. Fresh air flow is adjusted by motorized dampers which are controlled by temperature and indoor air quality sensors. Moreover, the AHUs have a free-cooling function to increase the supply of fresh air if the outdoor air temperature is lower than the indoor. AHU are manually controlled by local controllers in spaces, and they are connected to BEMS from where they are monitored and controlled as well. AHU have a nominal electric power of $44.300 \mathrm{~W}$ and a nominal air flow of $49.310 \mathrm{~m}^{3} / \mathrm{h}$.

Heat Recovery Units (HRU) extract air from the return grilles of rooms and supply fresh air at the return of Fan Coil Units to be cooled or heated. HRUs are controlled by local air-conditioning controllers in offices, and they are connected to BEMS from where they are monitored and controlled as well. HRUs have a nominal electric power of $1.972 \mathrm{~W}$ and a nominal air flow of $4.960 \mathrm{~m}^{3} / \mathrm{h}$.

Lighting is achieved with compact fluorescent lamps, T8 fluorescents, and metal halide lamps, which are controlled by local on/off switches. Total lightning power is $41.700 \mathrm{~W}$.

Four different wall types W1-W4 have been implemented as shown in Fig. 11 with U-valueWALL1 $=0.249 \mathrm{~W} / \mathrm{m}^{2} \mathrm{~K}$, UvalueWALL2 $=0.305 \mathrm{~W} / \mathrm{m}^{2} \mathrm{~K}, \quad \mathrm{U}$-valueWALL3 $=0.294 \mathrm{~W} / \mathrm{m}^{2} \mathrm{~K}$, UvalueWALL4 $=0.295 \mathrm{~W} / \mathrm{m}^{2} \mathrm{~K}$ respectively [52].

Both extruded polystyrene and stone-wool have been used for thermal insulation. Also, for the windows and window doors, double glazing has been used. The glazing is consisted of $4 \mathrm{~mm}$ of low emittance glass - $16 \mathrm{~mm}$ air - $4 \mathrm{~mm}$ low emittance glass with Ugvalue $=1.4 \mathrm{~W} /\left(\mathrm{m}^{2} \mathrm{~K}\right)$, light transmission $71 \%$ and solar factor $42 \%$. Moreover, at the east and west side of the building, perforated galvanized sheet iron has been installed with $60 \%$ percentage of perforation.

A rooftop installation of 62 panels, $180 \mathrm{Wp}$ each $(11.16 \mathrm{kWp}$ total) with a small installation of $54 \mathrm{biPV}$ shadowing panels, $62 \mathrm{Wp}$ each (3.348 kWp total) in the south façade partially covers the electricity consumption of NTL.

During energy auditing, it has been observed that the initial design of the building was aimed to ensure the minimum energy consumption: insulation and shadowing have been introduced, efficient lamps have been used for lighting and controls for ventilation, heat recovery units and air flow have been installed. 


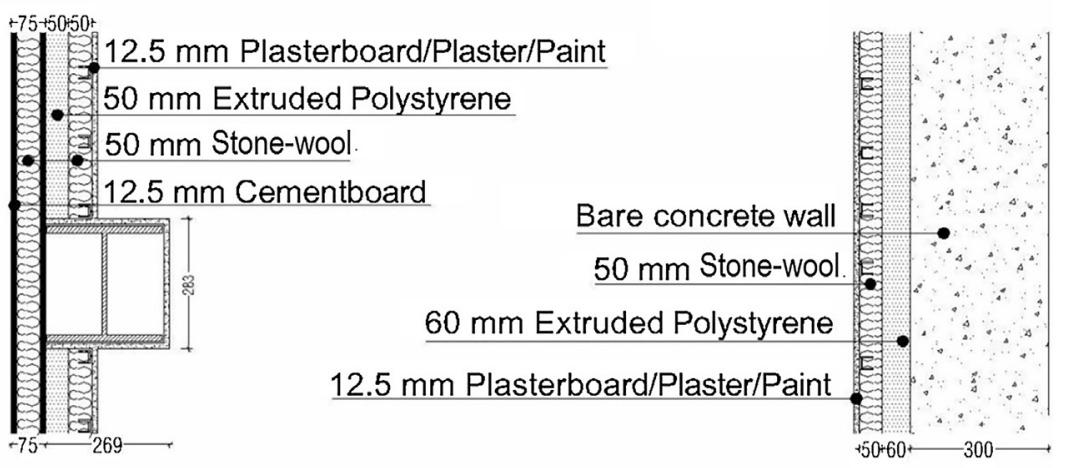

WALL W3

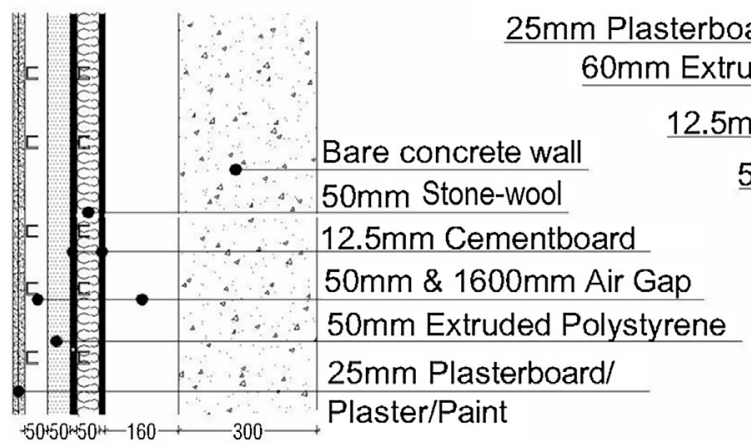

WALL W4

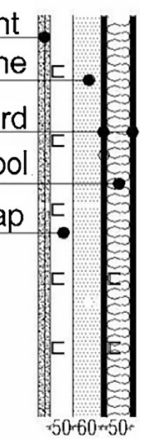

Fig. 11. Different wall structures and materials applied in NTL building.

However, geothermal and solar thermal systems have not been envisaged from the beginning, neither have lighting control systems and intelligent control of the air flow in each room or section.

The introduction of an innovative system has been taken into account and, in particular, the installation of an integrated solar cooling system in an advanced state under the above mentioned STS-Med project. This pilot plan at the Cyprus Institute relies on a Fresnel collector that has been installed on the rooftop of a school just in front of the NTL building.

This collector has been specifically designed by Idea Srl to assure the independent rotation of each collecting element of the primary optics. This allows the complete rotation of the supports that can host in future a PV panel on the back to provide electrical energy in the absence of a suitable direct radiation for thermal energy exploitation.

The technical specifications and main features of the Linear Fresnel collector connected to Novel Technologies Laboratory are listed in Table 4.

The main thermal loops that have been implemented are:

1. Thermal oil loop: the heating medium which circulates inside the Fresnel collector, equipped with small buffer to preheat the oil and Nitrogen pressurized (3 bar) system in order to maintain the oil above a minimum pressure.

2. Thermal storage loop: pressurized water, able to store the heat produced by the Fresnel collector up to $2 \mathrm{~h}$ for cooling and $4 \mathrm{~h}$ for heating; an expansion tank maintains the water at high pressure (up to 8 bar).

3. Heating-medium loop: hot water to fire the absorption chiller, equipped with a small buffer.

4. Heat recovery loop: hot water to support heating in winter.
Table 4

Main features of the installed LFR System.

\begin{tabular}{ll}
\hline Element & Characteristics \\
\hline Mirrors & 288 mirrors (2000 $\mathrm{mm} \times 320 \mathrm{~mm}$ dimension \\
& per unit) \\
& Global aperture area of $184.32 \mathrm{~m}^{2}$ \\
& Three focusing distances according to the \\
& position of each row \\
& 144 collecting units distributed into 18 \\
& rows 8 modules \\
& 72 DC motors ( 1 for a couple of collecting \\
& units) controlled by 18 PLC/36 drivers \\
Motorization & $32 \mathrm{~m}$ long \\
& Secondary reflector on top \\
Receiver & Vacuum tube receiver \\
& $8 \mathrm{t}$ distributed on 9 beams \\
Weight & Receiver is aligned with the local meridian \\
Orientation & White oil (Duratherm 450$)$ \\
Heat transfer fluid & $70 \mathrm{~kW}$ \\
Maximum thermal power & $170{ }^{\circ} \mathrm{C}$ outlet nominal temperature \\
&
\end{tabular}

5. HVAC chiller loop: a chilled circuit that is connected to the previously implemented HVAC system of the Novel Technologies Laboratory.

A schematic representation of the loop is provided in Fig. 12.

\subsection{NTL modelling}

The thermal energy annually provided by the solar collector has been evaluated, using an hourly steady-state model that simulated the annual solar energy gain. 

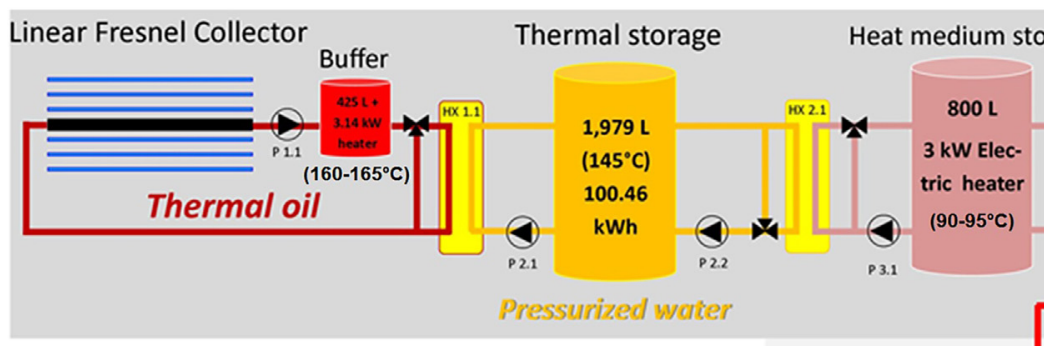

\section{wares}

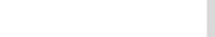
zed waber

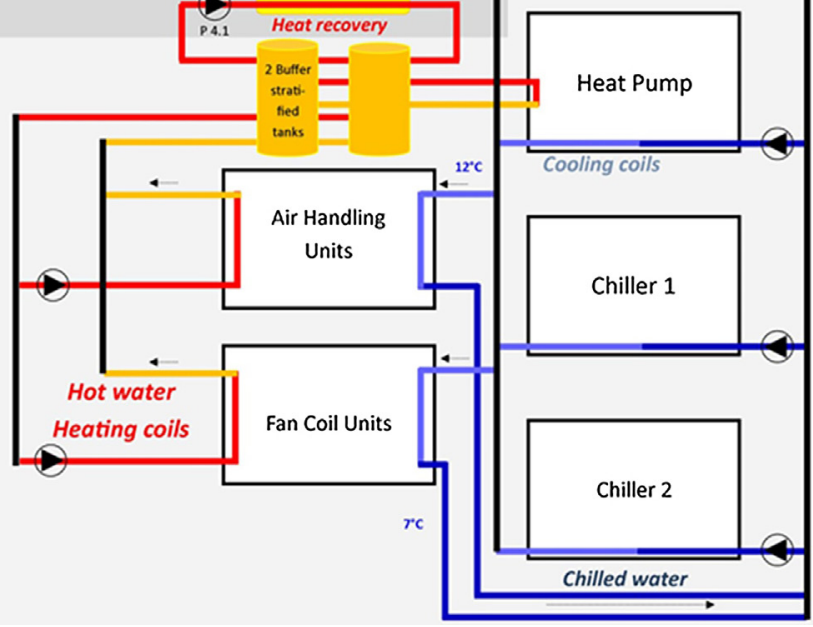

Fig. 12. Layout of the SHC (Solar Heating and Cooling) system and integration with HVAC system in NTL.

A tool has been developed by the authors (using a spreadsheet) to calculate the hourly thermal energy produced by the LFR collector. Starting from hourly values of astronomical coordinate relative to the sun position (Azimuth, Elevation) generated using SOLRAD [53] v 16.0 tool, the optical features of the LFR, like Incident Angle Modifier (IAM transversal, IAM longitudinal), "end effect" factor and optical efficiency were calculated.

The weather data, used for the hourly simulation, were generated by Meteonorm [54] version 7.1 with an interpolation mode from the hourly base.

Thermal losses of absorber pipes were calculated, according to equations applicable to concentrating solar collector, as defined by Kalogirou [55] UNI EN ISO 9806 (Solar Thermal Collectors: Test Methods). Results in term of thermal energy produced by LFR, calculated through a steady-state model instead of a quasi-dynamic model, could be affected by an overestimation error lower than $10 \%$ [56]. Thus, values of thermal energy gain have been reduced by $10 \%$, to correct this error.

To estimate the heating and cooling energy that could be supplied by the single-effect absorption chiller system, the thermal capacity of the storage system in operative conditions was calculated. In this analysis, as it was not possible to use an energy building model to describe the hourly thermal needs of the building, values of electric energy consumption provided by the metering system installed in the building were considered. The metering system collects every $15 \mathrm{~min}$ the cumulative consumption data for lighting, power, HVAC for each floor, as well as the generation of electricity by the PV system installed on the rooftop. Full datasets available for the years 2014 and 2015 were exploited.

The two diagrams of Fig. 13 show how a large part of the electric energy consumption is attributable to the HVAC system, respectively $69 \%$ in 2014 and $72 \%$ in 2015 , with an increase of $6500 \mathrm{kWh}$ in one year. It is noted that energy for specialised research related activities of the laboratories is not accounted for in these diagrams. The installed PV system has covered the $27 \%$ of the annual electric energy consumption of the building (offices, without laboratories). This percentage is almost the same in both years. The increase is partially due to the increased number employees from 2014 to 2015, as well as to heavier climatic conditions in 2015.

The electrical energy consumptions in 2014 and 2015, due to the HVAC system, were assigned to Heating and Cooling and normalized, considering the HDD (base temperature $=19^{\circ} \mathrm{C}$ ) and $\mathrm{CDD}$ (base temperature $26^{\circ} \mathrm{C}$ ) calculated using data collected by the closest available weather station (LCNC - 17607 - Athalassa, CY - 33.40E; $35.14 \mathrm{~N}$ ) (Table 5). The base temperatures were chosen in accordance with the study conducted by Theophiloua and Serghides [57].

\subsection{NTL energy performance}

The impact of the solar cooling system has been simulated in two scenarios. The first one assumes the nominal optical efficiency of the LFR solar field at $46 \%$. In the second scenario, the optical efficiency was set to $60 \%$ achievable with a potential improvement of the control of the mirrors.

The histogram of Fig. 14 shows the thermal energy monthly gained by the LFR system in the first scenario (optical efficiency at $46 \%$ ). Table 6 shows the main values of thermal energy production.

In the second scenario presented in Fig. 15 and Table 7 (optical efficiency at 60\%), the annual solar thermal energy production could be increased by more than $30 \%$, reaching approximately $104 \mathrm{MWh}$.

To compare the share of the SHC in covering the thermal energy building demand in each scenario (Table 8 ) the following assumption were made 


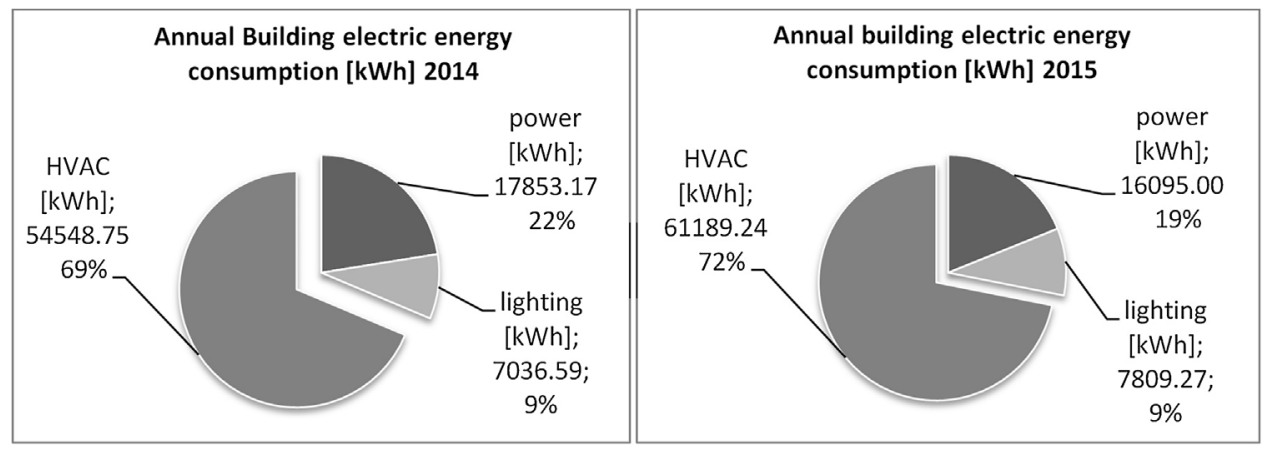

Fig. 13. Categorized electrical energy consumption [kWh, \%] of NTL in 2014 and 2015.

Table 5

NTL Electric Energy Consumption in 2014 and 2015 due to HVAC system, normalized with respective HDD (Heating Degree Days) and CDD (Cooling Degree Days).

\begin{tabular}{|c|c|c|c|c|c|c|}
\hline & $\begin{array}{l}\text { Electric Energy } \\
\text { Consumption in } \\
\text { Heating (HVAC) } \\
\text { [kWhe] }\end{array}$ & $\begin{array}{l}\operatorname{HDD}\left[{ }^{\circ} \mathrm{C}^{*} \text { Day }\right] \\
\text { (base tempera- } \\
\text { ture }=19{ }^{\circ} \mathrm{C} \text { ) }\end{array}$ & $\begin{array}{l}\text { Normalized } \\
\text { Electric energy } \\
\text { consumption } \\
\text { [kWhe/HDD] }\end{array}$ & $\begin{array}{l}\text { Electric Energy } \\
\text { Consumption in } \\
\text { Cooling (HVAC) } \\
\text { [kWhe] }\end{array}$ & $\begin{array}{l}\mathrm{CDD}\left[{ }^{\circ} \mathrm{C}^{*} \text { Day }\right] \\
\text { (base tempera- } \\
\text { ture }=26^{\circ} \mathrm{C} \text { ) }\end{array}$ & $\begin{array}{l}\text { Normalized } \\
\text { Electric energy } \\
\text { consumption } \\
\text { [kWhe/CDD] }\end{array}$ \\
\hline 2014 & 22783.04 & 692.7 & 32.9 & 31765.71 & 684.8 & 46.4 \\
\hline 2015 & 24774.91 & 788.1 & 31.4 & 36224.47 & 810 & 44.7 \\
\hline Variation [\%] & $9 \%$ & $14 \%$ & $-4 \%$ & $14 \%$ & $18 \%$ & $-4 \%$ \\
\hline
\end{tabular}

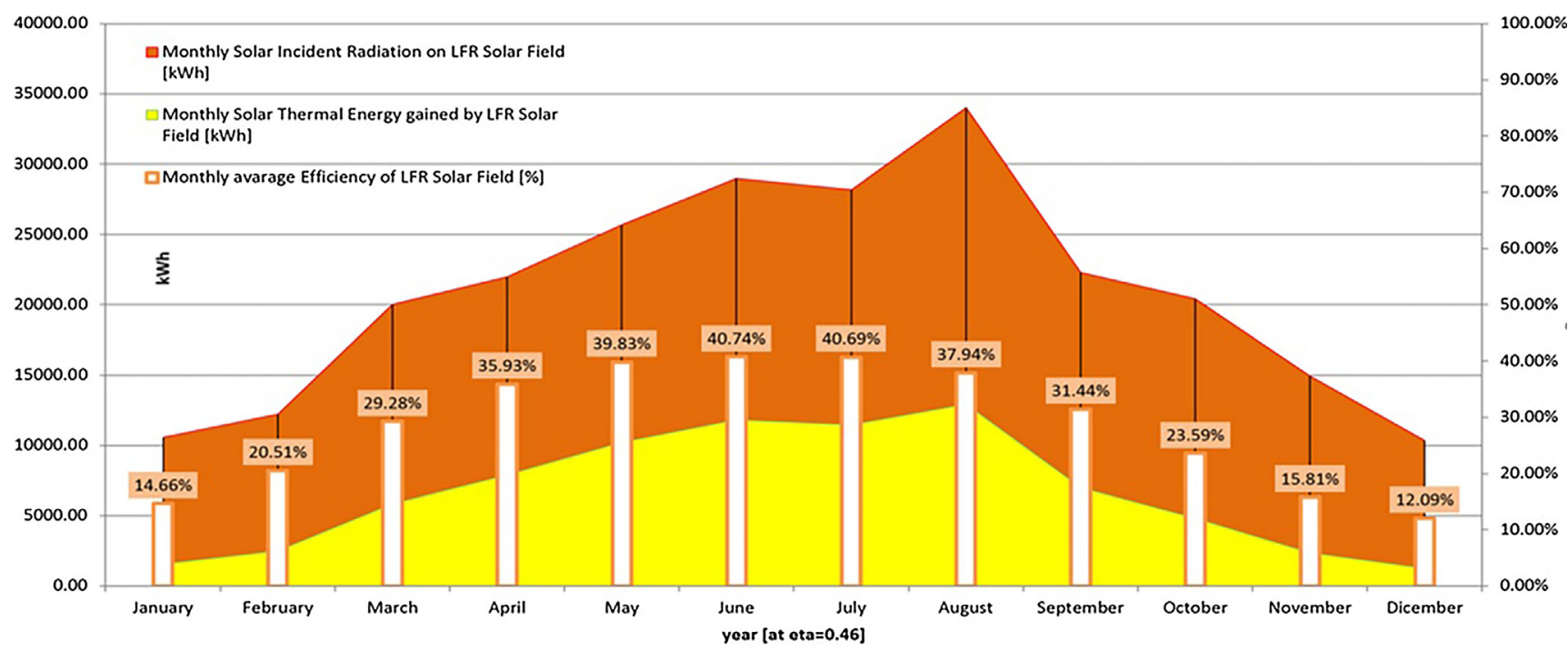

Fig. 14. Histogram of monthly thermal energy gained by LFR system and monthly average efficiency in Scenario 1 (optical efficiency = 46\%).

Table 6

Main monthly thermal energy features of LFR production in Scenario 1.

\begin{tabular}{|c|c|c|c|c|c|}
\hline Month & $\begin{array}{l}\text { Monthly Solar } \\
\text { Thermal Energy } \\
\text { gained by LFR } \\
\text { Solar Field [kWh] }\end{array}$ & $\begin{array}{l}\text { Monthly Solar } \\
\text { Incident } \\
\text { Radiation on LFR } \\
\text { Solar Field [kWh] }\end{array}$ & $\begin{array}{l}\text { Monthly average } \\
\text { Efficiency of LFR } \\
\text { Solar Field [\%] }\end{array}$ & Peak Power [KW] & $\begin{array}{l}\text { Monthly Therma } \\
\text { Peak Efficiency o } \\
\text { LFR [\%] }\end{array}$ \\
\hline January & 1548.8 & $10,567.7$ & $14.6 \%$ & 25.7 & $19.2 \%$ \\
\hline February & 2509.7 & $12,235.2$ & $20.5 \%$ & 35.9 & $27.2 \%$ \\
\hline March & 5858.9 & $20,006.9$ & $29.3 \%$ & 53.0 & $35.3 \%$ \\
\hline April & 7895.9 & $21,977.7$ & $35.9 \%$ & 69.1 & $40.4 \%$ \\
\hline May & 1225.4 & $25,674.5$ & $39.8 \%$ & 64.5 & $43.2 \%$ \\
\hline June & $11,807.1$ & $28,983.0$ & $40.7 \%$ & 70.1 & $43.8 \%$ \\
\hline July & $11,459.41$ & $28,164.9$ & $40.7 \%$ & 71.5 & $43.8 \%$ \\
\hline August & $12,903.6$ & $34,013.7$ & $37.9 \%$ & 62.8 & $42.1 \%$ \\
\hline September & 7010.2 & $22,294.9$ & $31.4 \%$ & 51.3 & $37.4 \%$ \\
\hline October & 4819.3 & $20,431.5$ & $23.6 \%$ & 45.4 & $30.2 \%$ \\
\hline November & 2363.6 & $14,951.6$ & $15.8 \%$ & 28.6 & $21.2 \%$ \\
\hline December & 1247.4 & $10,320.1$ & $12.1 \%$ & 19.5 & $14.6 \%$ \\
\hline Total Year & $79,649.4$ & $249,622.3$ & $31.9 \%$ & Optical efficiency $=46 \%$ & \\
\hline
\end{tabular}




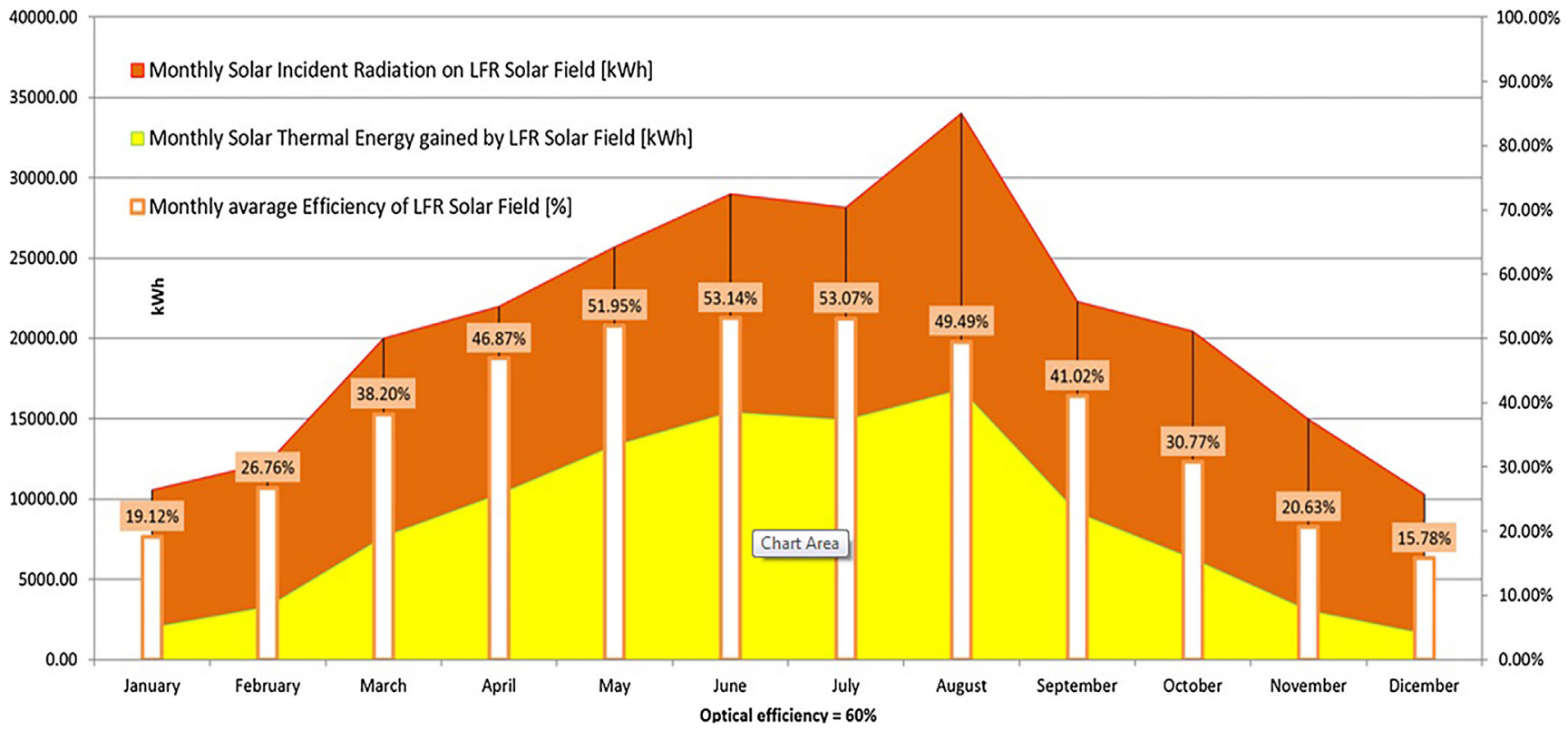

Fig. 15. Histogram of monthly thermal energy gained by LFR system and monthly average efficiency in Scenario 2 (optical efficiency=60\%).

Table 7

Main monthly thermal energy features of LFR production in Scenario 2.

\begin{tabular}{|c|c|c|c|c|c|}
\hline Month & $\begin{array}{l}\text { Monthly Solar } \\
\text { Thermal Energy } \\
\text { gained by LFR } \\
\text { Solar Field [kWh] }\end{array}$ & $\begin{array}{l}\text { Monthly Solar } \\
\text { Incident } \\
\text { Radiation on LFR } \\
\text { Solar Field [kWh] }\end{array}$ & $\begin{array}{l}\text { Monthly Average } \\
\text { Efficiency of LFR } \\
\text { Solar Field [\%] }\end{array}$ & $\begin{array}{l}\text { Thermal Peak } \\
\text { Power [KW] }\end{array}$ & $\begin{array}{l}\text { Monthly Thermal } \\
\text { Peak Efficiency of } \\
\text { LFR [\%] }\end{array}$ \\
\hline January & 2020.9 & $10,567.7$ & $19.1 \%$ & 33.6 & $25.0 \%$ \\
\hline February & 3274.4 & $12,235.2$ & $26.7 \%$ & 46.8 & $35.5 \%$ \\
\hline March & 7643.2 & $20,006.9$ & $38.2 \%$ & 69.2 & $45.9 \%$ \\
\hline April & $10,300.0$ & $21,977.8$ & $46.8 \%$ & 90.2 & $52.7 \%$ \\
\hline May & $13,338.7$ & $25,674.5$ & $51.9 \%$ & 84.2 & $56.3 \%$ \\
\hline June & $15,401.6$ & $28,983.0$ & $53.1 \%$ & 91.5 & $57.2 \%$ \\
\hline July & $14,948.1$ & $28,164.9$ & $53.1 \%$ & 93.2 & $57.1 \%$ \\
\hline August & $16,832.1$ & $34,013.8$ & $49.5 \%$ & 81.9 & $54.8 \%$ \\
\hline September & 9144.8 & $22,294.9$ & $41.0 \%$ & 66.9 & $48.8 \%$ \\
\hline October & 6286.9 & $20,431.6$ & $30.8 \%$ & 59.3 & $39.4 \%$ \\
\hline November & 3083.9 & $14,951.7$ & $20.6 \%$ & 37.4 & $27.6 \%$ \\
\hline December & 1628.1 & $10,320.2$ & $15.8 \%$ & 25.5 & $19.1 \%$ \\
\hline Total Year & $103,902.87$ & $249,622.3$ & $41.6 \%$ & Optical efficiency $=60 \%$ & \\
\hline
\end{tabular}

- $10 \%$ of thermal energy losses in piping systems, storage systems;

- Thermal $\mathrm{COP}=1.0$ in heating mode, and $\mathrm{COP}=0.7$ in cooling mode for the SHC system;

- $\mathrm{EER}=2.3$ and $\mathrm{SEER}=4$ in cooling mode and $\mathrm{COP}=3.15$ in heating mode for chillers and heat pumps of the HVAC system;

- The hourly electric consumption of the SHC is set to $3.5 \mathrm{kWh}$ in cooling mode and $2.0 \mathrm{kWh}$ per hour in heating mode (since in heating mode the absorption chiller and the cooling tower are OFF).

Actual COP of each system could not be calculated because the external air temperature and the hourly thermal energy needs of the building have not been registered. As for the scope of this work, only the nominal values were considered. In the purpose of further investigation and more accurate simulations, temperature sensors of outdoor temperature should be installed. Main monthly results of 2015 simulations and the corresponding electrical energy savings due to cooling and heating energy provided by SHC in Scenario 1 (optical efficiency 46\%) and Scenario 2 (optical efficiency 60\%) are presented in Table 8.

In Scenario 1, the SHC system could yearly cover about of $26 \%$ of thermal needs of the building, with an average energy saving effect on the HVAC electric energy consumptions of about 28\% (Fig. 16).
In Scenario 2, the SHC rate could be higher than 33\% regarding thermal needs of the building with an energy saving effect on HVAC electric consumptions of about $40 \%$ (Fig. 17). In this case, the simulations show that absorption chiller capacity should be improved by $30 \%$ to get the full benefit of the energy collected by the solar field. During the spring, the SHC is able to cover about $70 \%$ of the thermal energy needs of the NTL building. According to Scenario 2, this value reaches $100 \%$ in the month of April.

An important improvement of the SHC system is envisaged by (i) introducing a double-effect Absorption Chiller, instead of a singleeffect one, and (ii) covering the back side of LFR mirrors structures with PV panels able to convert diffuse solar radiation, when the direct one is too poor for concentration and when the building does not need cooling or heating services.

In this configuration, the LFR could work in thermal mode during working days with DNI higher than $300 \mathrm{~W} / \mathrm{m}^{2}$. It could switch in PV mode if DNI is lower than $300 \mathrm{~W} / \mathrm{m}^{2}$, and during weekend or holidays. This smart configuration could increase the annual amount of energy saving contribution of the LFR solar field from $28 \%$ to $38 \%$ of the electrical energy demand of the NTL building. 
Table 8

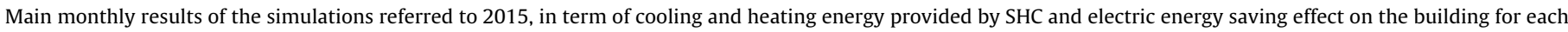
scenario.

\begin{tabular}{|c|c|c|c|c|c|c|c|c|}
\hline 2015 & Month & $\begin{array}{l}\text { Monthly SHC } \\
\text { capacity [kWh] }\end{array}$ & $\begin{array}{l}\text { Monthly HVAC } \\
\text { thermal supply } \\
\text { [kWh] }\end{array}$ & $\begin{array}{l}\text { Building thermal } \\
\text { needs covered by } \\
\text { SHC [\%] }\end{array}$ & $\begin{array}{l}\text { Monthly HVAC } \\
\text { electric energy } \\
\text { consumptions } \\
{[\mathrm{kWh}]}\end{array}$ & $\begin{array}{l}\text { Monthly HVAC } \\
\text { electric energy } \\
\text { consumptions } \\
\text { with SHC [kWh] }\end{array}$ & $\begin{array}{l}\text { Monthly SHC } \\
\text { electric energy } \\
\text { saving [kWh] }\end{array}$ & $\begin{array}{l}\text { HVAC electric } \\
\text { energy saving } \\
\text { due to SHC [\%] }\end{array}$ \\
\hline \multirow{13}{*}{$\begin{array}{l}\text { Scenario } 1 \text { (Optical } \\
\text { efficiency at } 46 \% \text { ) }\end{array}$} & January & 1471.3 & $19,819.8$ & $7.4 \%$ & 6384.8 & 5949.6 & 435.1 & $6.8 \%$ \\
\hline & February & 2384.2 & $18,785.4$ & $12.7 \%$ & 5942.2 & 4997.5 & 944.6 & $15.9 \%$ \\
\hline & March & 5259.9 & $11,012.1$ & $47.8 \%$ & 3374.9 & 2134.1 & 1240.7 & $36.7 \%$ \\
\hline & April & 6172.6 & $7,743.9$ & $79.7 \%$ & 2237.2 & 821.7 & 1415.5 & $63.2 \%$ \\
\hline & May & 6896.0 & $11,060.2$ & $62.4 \%$ & 3151.5 & 1163.0 & 1988.4 & $63.1 \%$ \\
\hline & June & 7851.7 & $19,320.8$ & $40.6 \%$ & 5292.4 & 2476.6 & 2815.7 & $53.2 \%$ \\
\hline & July & 7620.5 & $34,985.8$ & $21.8 \%$ & 8315.0 & 5966.7 & 2348.2 & $28.2 \%$ \\
\hline & August & 8580.9 & $34,022.3$ & $25.2 \%$ & 9259.4 & 5571.1 & 3688.3 & $39.8 \%$ \\
\hline & September & 4661.7 & $34,200.6$ & $13.6 \%$ & 7968.7 & 6715.0 & 1253.7 & $15.7 \%$ \\
\hline & October & 3233.4 & 12,927 & $25.0 \%$ & 3345.3 & 2782.3 & 563.0 & $16.8 \%$ \\
\hline & November & 1874.7 & 5446.6 & $34.4 \%$ & 1784.1 & 1550.4 & 233.7 & $13.1 \%$ \\
\hline & December & 1135.2 & $13,264.9$ & $8.6 \%$ & 3943.4 & 3803.1 & 140.2 & $3.5 \%$ \\
\hline & Annual & $57,142.4$ & $222,589.8$ & $25.7 \%$ & $60,999.3$ & $43,931.7$ & $17,067.5$ & $27.9 \%$ \\
\hline \multirow{13}{*}{$\begin{array}{l}\text { Scenario } 2 \text { (Optical } \\
\text { efficiency at } 60 \% \text { ) }\end{array}$} & January & 1919.8 & $19,819.8$ & $9.7 \%$ & 6384.8 & 5743.2 & 641.61 & $10.0 \%$ \\
\hline & February & 3110.6 & $18,785.4$ & $16.6 \%$ & 5942.2 & 4631.7 & 1310.5 & $22.0 \%$ \\
\hline & March & 6861.8 & $11,012.1$ & $62.3 \%$ & 3374.9 & 1634.6 & 1740.2 & $51.5 \%$ \\
\hline & April & 8052.0 & 7743.9 & $104.0 \%$ & 2237.2 & 210.6 & 2026.5 & $90.5 \%$ \\
\hline & May & 8995.7 & $11,060.2$ & $81.3 \%$ & 3151.5 & 305.2 & 2846.2 & $90.3 \%$ \\
\hline & June & $10,242.1$ & $19,320.8$ & $53.0 \%$ & 5292.4 & 1353.1 & 3939.3 & $74.4 \%$ \\
\hline & July & 9940.4 & $34,985.8$ & $28.4 \%$ & 8315.0 & 4991.8 & 3323.1 & $39.9 \%$ \\
\hline & August & $11,193.3$ & $34,022.3$ & $32.9 \%$ & 9259.4 & 4144.5 & 5114.9 & $55.2 \%$ \\
\hline & September & 6081.2 & $34,200.6$ & $17.8 \%$ & 7968.7 & 6115.8 & 1852.9 & $23.2 \%$ \\
\hline & October & 4218.1 & $12,927.0$ & $32.6 \%$ & 3345.5 & 2415.9 & 929.4 & $27.7 \%$ \\
\hline & November & 2446.1 & 5446.6 & $44.9 \%$ & 1784.1 & 1354.8 & 429.3 & $24.0 \%$ \\
\hline & December & 1481.7 & $13,264.9$ & $11.2 \%$ & 3943.4 & 3687.5 & 255.8 & $6.4 \%$ \\
\hline & Annual & $74,543.2$ & $222,589.8$ & $33.5 \%$ & $60,999.3$ & $36,589.2$ & $24,410.1$ & $40.0 \%$ \\
\hline
\end{tabular}

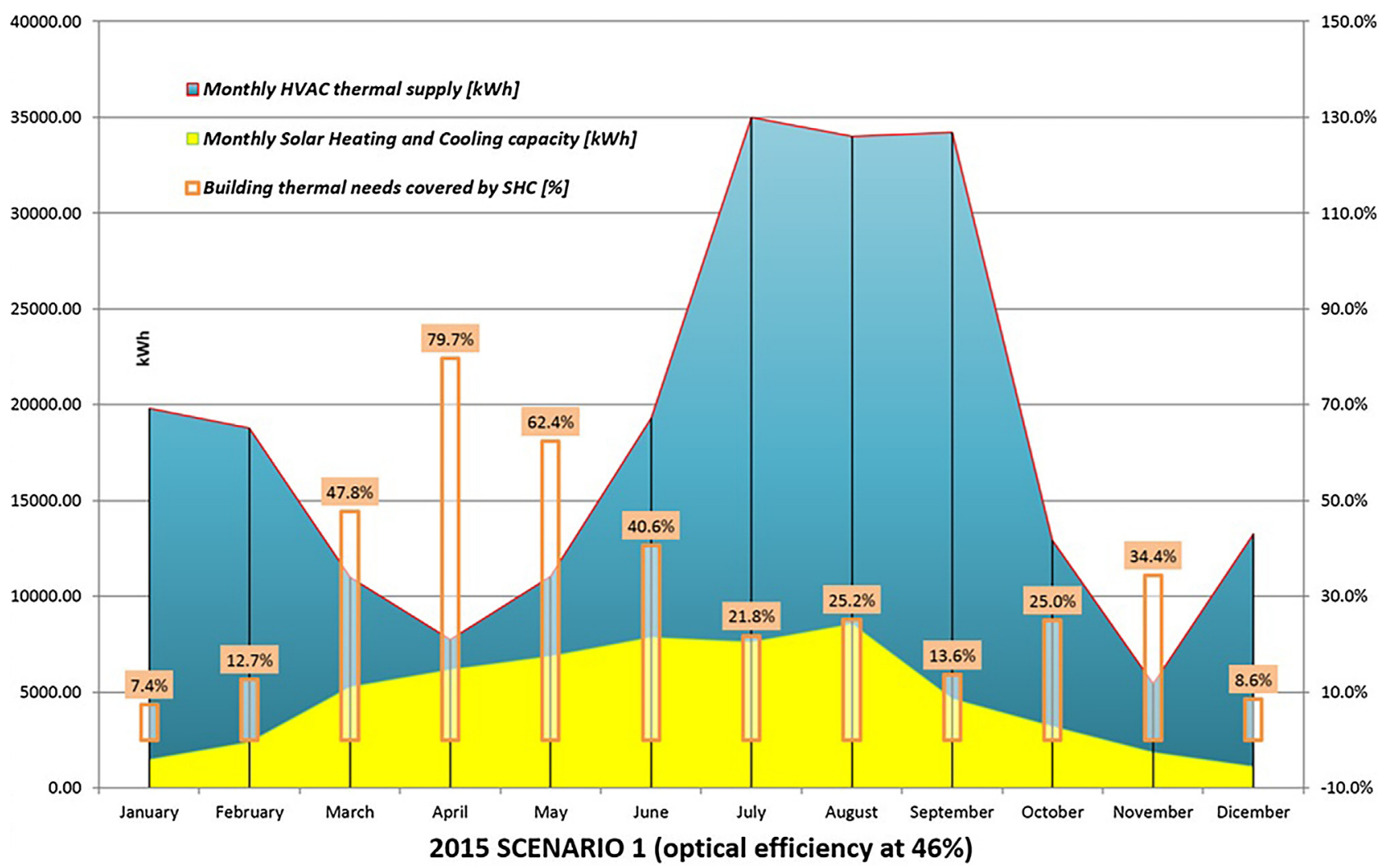

Fig. 16. NTL monthly thermal demand covered by SHC system in Scenario 1 .

\section{Discussion}

In the selected case studies the performance gap is finally assessed by comparing design and operational primary energy consumption in Table 9:
With regards to the Leaf Lab the net normalised primary energy in the operational phase is deduced by extracting energy dissipated for industrial purposes as this is not taken into consideration in the corresponding design value. According to the results there is 


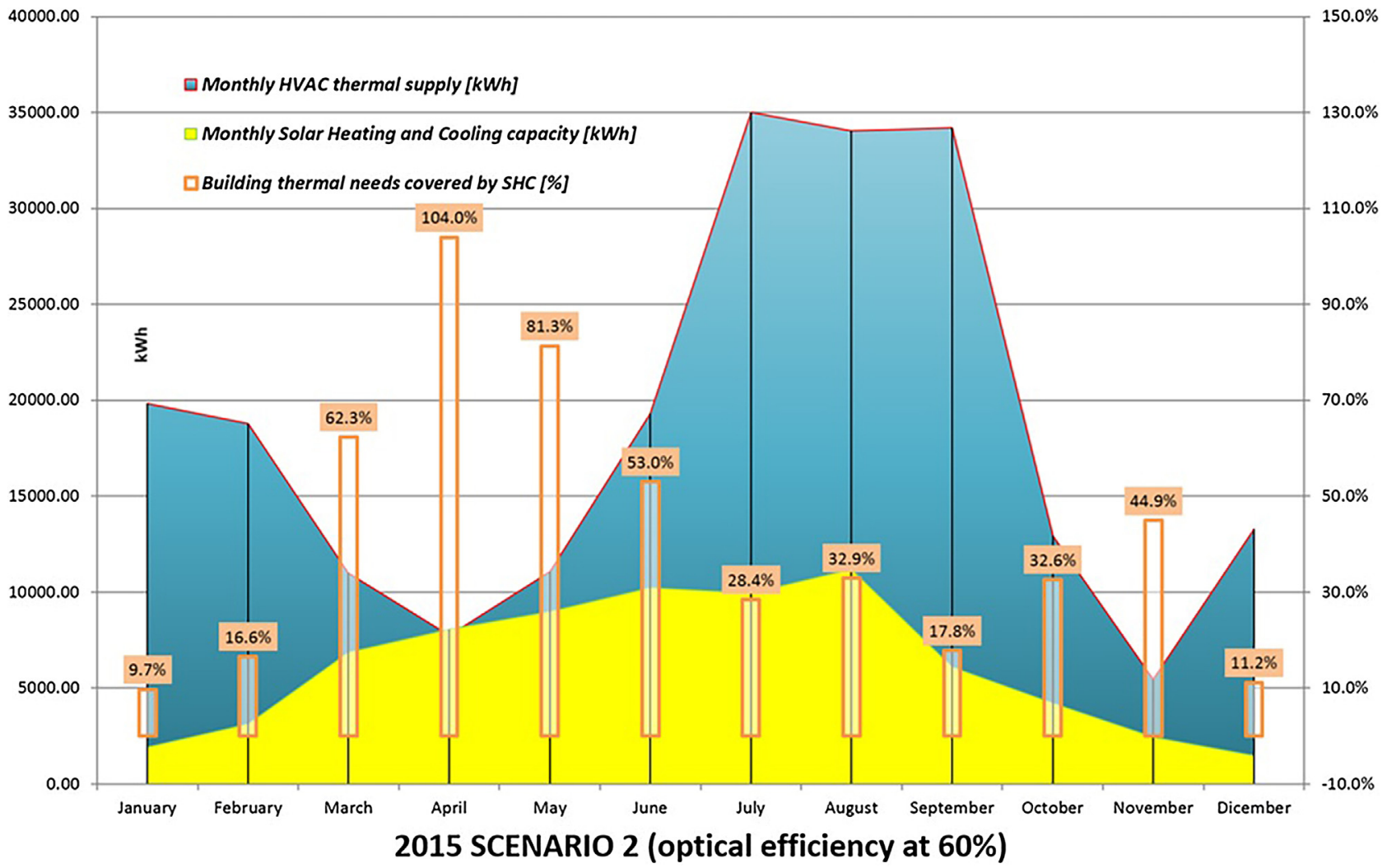

Fig. 17. NTL monthly thermal demand covered by SHC system in Scenario 2 .

Table 9

Normalised primary energy consumption in the design and operational phase.

\begin{tabular}{|c|c|c|}
\hline Pilot case study & Normalised Primary Energy Consumption in Design Phase $\left(\mathrm{kWh} / \mathrm{m}^{2}\right)$ & Normalised Net Primary Energy Consumption in Operational Phase $\left(\mathrm{kWh} / \mathrm{m}^{2}\right)$ \\
\hline Leaf Lab & 26.9 & 35.4 \\
\hline Leaf House & 19.6 & 54.4 \\
\hline NTL & 64.4 & 62.9 \\
\hline
\end{tabular}

a relatively low difference of $8.5 \mathrm{kWh} / \mathrm{m}^{2}$ in primary energy consumption which is not considered particularly significant.

In the case of the Leaf House the performance gap is of higher magnitude and in specific $34.8 \mathrm{kWh} / \mathrm{m}^{2}$ of primary energy consumption. A possible explanation for - at least - part of this performance gap is that the energy classification process (in Italy or elsewhere) does not take into account energy for lighting or other appliances as it depends on residents' behaviour or other factors that cannot be standardised and applied as a common assessment framework. One issue that requires further investigation is whether the high thermal inertial of underfloor heating in the Leaf House could be controlled using predictive control to improve energy efficiency and indoor comfort levels. Another critical issue associated with the performance gap in the Leaf House is the engagement of residents in terms of their capability in controlling building systems, their understanding of the actual potential in saving energy and their motivation in this direction. Despite the fact that residents of Leaf Lab enjoy an elaborate monitoring and control interface, it has not been adequately explored if a performance gap may be linked to a lack of understanding or low commitment in addressing energy savings. An important parameter in this direction is that residents in the Leaf Lab are often visitors who do not permanently reside in the building but in an ad-hoc fashion.

With regards to the NTL building, taking into account initial design assumptions results to an insignificant performance gap. This is especially true when energy consumption based on HVAC and lights is considered excluding power consumption of laboratories. It is to be evidenced that the most relevant effect of the SHC introduction is an improved seasonal balance between demand and generation from renewable sources, smoothing the summer peak of electrical demand for air conditioning. An important improvement of the SHC system has been envisaged by (i) introducing a double-effect Absorption Chiller, instead of a single-effect one, and (ii) covering the back side of LFR mirrors structures with PV panels able to convert diffuse solar radiation, when the direct one is too poor for concentration and when the building doesn't need cooling or heating services. In this configuration, the LFR could work in thermal mode during working days with DNI higher than $300 \mathrm{~W} / \mathrm{m}^{2}$ and it could be switched in PV mode if DNI is lower than $300 \mathrm{~W} / \mathrm{m}^{2}$, and during weekend or holidays. According to preliminary calculations, this smart configuration could increase the annual amount of energy saving contribution of the LFR solar field from 28\% to 38\% of the electrical energy demand.

Overall in the examined cases, the performance gap is either not particularly significant or it can be possibly addressed by technical improvements or changes related to the human activity. In the case of the Leaf Lab and the Leaf House this is largely due to the integrated design which had as a starting point the targeted the implementation of state of the art techniques, technologies and know-how for achieving Near-Zero energy goals. In the case of the Leaf House technical measures such as predictive control could possibly provide a smart solution in avoiding energy waste 
and improving indoor conditions. On the other hand training about available controls, behavioral change and active engagement can be especially important for residents to become proactive in reducing energy consumption. Behavioral change can be achieved in a number of ways including gamification i.e. competitions between apartments or enrolment in rewarding (future) Demand Response programs.

In the case of the NTL, renovation design and implementation activities were consistent and effective in setting energy efficiency targets, reshaping the envelope and integrating smart controls as well as the Linear Fresnel Collector system into the building service operations.

\section{Conclusions}

In this paper, the operational performance of industrial, residential and research/educational buildings has been investigated, analysed and optimized with the use of dynamic and quasidynamic simulation tools. Energy efficient technologies, renewable energy technologies, storage, as well as smart monitoring and controls have been audited to evaluate their significance for smart near-zero energy buildings in different sectors. Various performance indicators have been used in this analysis including normalized electrical and primary energy consumption. Smart monitoring and indoor conditions measurements have been exploited to allow the extraction of robust results and the validation of dynamic building energy models. The above analysis reveals the significance in evaluating the actual performance gap in Nearzero Energy Buildings and provide the basis for decision making and smart adjustments as necessary. In all three cases, apart from the high quality building envelopes, the Near-Zero target is largely pursued by renewable energy technologies and the implementation of advanced monitoring and controls. Furthermore, in all test cases there is a systematic and continuous approach in establishing near-zero energy targets through research and innovation activities. In this direction, predictive control, behavioral change and proactive users' engagement have been identified as potential areas for addressing energy efficiency improvements in the future.

\section{Acknowledgement}

This project has received funding from the European Union's Horizon 2020 research and innovation programme under the Marie Skłodowska-Curie grant agreement No 645677.

\section{References}

[1] EU, Directive 2010/31/EU of the European Parliament and of the Council of 19 May 2010 on the energy performance of buildings (recast), Off. J. Eur. Union (2010) 13-35, http://dx.doi.org/10.3000/17252555.L_2010.153.eng.

[2] A Roadmap for Moving to a Compet Itive Low Carbon Economy in 2050, 2011, pp. 16, http://eur-lex.europa.eu/legal-content/EN/TXT/PDF/ ?uri=CELEX:52011DC0112\&from=EN. (Accessed 8 December 2016).

[3] A.J. Marszal, P. Heiselberg, J.S. Bourrelle, E. Musall, K. Voss, I. Sartori, A. Napolitano, Zero Energy Building - a review of definitions and calculation methodologies, Energy Build. 43 (2011) 971-979.

[4] D. D'agostino, P. Zangheri, B. Cuniberti, D. Paci, P. Bertoldi, Synthesis Report on the National Plans for Nearly Zero Energy Buildings (NZEBs). (n.d.), doi:10.2790/012311.

[5] M. Scherberich, Jan Groezinger, Thomas Boermans, John Ashok, Jan Seehusen, Felix Wehringer, Overview of Member States Information on NZEBs Working Version of the Progress Report - Final Report, ECOFYS Germany GmbH, 2014, Cologne, https://ec.europa.eu/energy/sites/ener/files/documents/ Updated progress report NZEB.pdf. (Accessed 7 December 2016).

[6] P. Zangheri, L. Pagliano, V. Bürger, The Challenges, Dynamics and Activities in the Building Sector and Its Energy Demand in Italy D2.1 of WP2 from Entranze Project, 2012.

[7] E. Musall, Andreas Hemerlink, Sven Schimschar, Thomas Boermans, Lorenzo Pagliano, Paolo Zangheri, Roberto Armani, Karsten Voss, Towards Nearly Zero - Energy Buildings, Definition of Common Principles Under the EPBD, Final Report - Executive Summary, ECOFYS Germany GmbH, 2013, Köln, https://ec. europa.eu/energy/sites/ener/files/documents/nzeb_executive_summary.pdf. (Accessed 7 December 2016).

[8] D. Kolokotsa, K. Gobakis, S. Papantoniou, C. Georgatou, N. Kampelis, K. Kalaitzakis, K. Vasilakopoulou, M. Santamouris, Development of a web based energy management system for University Campuses: the CAMP-IT platform, Energy Build. 123 (2016) 119-135, http://dx.doi.org/10.1016/j.enbuild.2016. 04.038.

[9] D. Kolokotsa, D. Rovas, E. Kosmatopoulos, K. Kalaitzakis, A roadmap towards intelligent net zero- and positive-energy buildings, Sol. Energy 85 (2011) 3067-3084.

[10] Theoni Karlessi, Nikos Kampelis, Denia Kolokotsa, M. Santamouris, Towards sustainable and smart communities: integrating energy efficient technologies into buildings through a holistic approach, in: P. Bertoldi (Ed.), 9th Int. Conf. Improv. Energy Effic. Commer. Build. Smart Communities, Joint Research Centre, Frankfurt, 2016, pp. 920-927, http://dx.doi.org/10.2790/290244.

[11] Mapping Demand Response in Europe Today 2015, SEDC, Brussels, 2015.

[12] P. De Wilde, The gap between predicted and measured energy performance of buildings: a framework for investigation, Autom. Constr. 41 (2014) 40-49, http://dx.doi.org/10.1016/j.autcon.2014.02.009.

[13] A.C. Menezes, A. Cripps, D. Bouchlaghem, R. Buswell, Predicted vs. actual energy performance of non-domestic buildings: using post-occupancy evaluation data to reduce the performance gap, Appl. Energy 97 (2012) 355-364, http://dx.doi.org/10.1016/j.apenergy.2011.11.075.

[14] S. Papantoniou, D. Kolokotsa, K. Kalaitzakis, Building optimization and control algorithms implemented in existing BEMS using a web based energy management and control system, Energy Build. 98 (2015) 45-55, http://dx. doi.org/10.1016/j.enbuild.2014.10.083.

[15] D. Kolokotsa, C. Diakaki, E. Grigoroudis, G. Stavrakakis, K. Kalaitzakis, Decision support methodologies on the energy efficiency and energy management in buildings, Adv. Build. Energy Res. 3 (2009) 121-146.

[16] D. Kolokotsa, A. Pouliezos, G. Stavrakakis, C. Lazos, Predictive control techniques for energy and indoor environmental quality management in buildings, Build. Environ. 44 (2009) 1850-1863.

[17] D. Kolokotsa, The role of smart grids in the building sector, Energy Build. 116 (2016) 703-708, http://dx.doi.org/10.1016/j.enbuild.2015.12.033.

[18] D. Gao, Y. Sun, A GA-based coordinated demand response control for building group level peak demand limiting with benefits to grid power balance, Energy Build. 110 (2016) 31-40, http://dx.doi.org/10.1016/j.enbuild.2015.10.039.

[19] D. Gao, Y. Sun, Y. Lu, A robust demand response control of commercial buildings for smart grid under load prediction uncertainty, Energy 93 (2015) 275-283, http://dx.doi.org/10.1016/j.energy.2015.09.062.

[20] N. Kalkan, E.A. Young, A. Celiktas, Solar thermal air conditioning technology reducing the footprint of solar thermal air conditioning, Renew. Sustain. Energy Rev. 16 (2012) 6352-6383, http://dx.doi.org/10.1016/j.rser.2012.07. 014.

[21] K. Koutroulis, E. Kolokotsa, D. Potirakis, A. Kalaitzakis, Methodology for optimal sizing of standalone photovoltaic/wind generator systems using genetic algorithm, Sol. Energy 80 (2006) 1072-1088.

[22] E. Koutroulis, D. Kolokotsa, G. Stravrakakis, Optimal design and economic evaluation of a battery energy storage system for the maximization of the energy generated by wind farms in isolated electric grids. Vol 33 (2009) 55-81.

[23] E. Koutroulis, K. Kalaitzakis, Design of a maximum power tracking system for wind-Energy-Conversion applications, IEEE Trans. Ind. Electron. 53 (2006), http://dx.doi.org/10.1109/tie.2006.870658.

[24] E. Provata, D. Kolokotsa, S. Papantoniou, M. Pietrini, A. Giovannelli, G. Romiti, Development of optimization algorithms for the Leaf Community microgrid, Renew. Energy 74 (2015) 782-795, http://dx.doi.org/10.1016/j.renene.2014. 08.080 .

[25] Average Weather For Ancona, Italy - WeatherSpark. <https://weatherspark com/averages/32287/Ancona-Marche-Italy/>, n.d. (Accessed 6 March 2017).

[26] 3D modeling for everyone | SketchUp. <http://www.sketchup.com//>, n.d. (Accessed 13 February 2017).

[27] OpenStudio. <https://www.openstudio.net//>, n.d. (Accessed 13 February 2017).

[28] Building Technologies Office EnergyPlus Energy Simulation Software. <http://apps1. eere.energy.gov/buildings/energyplus//>, n.d. (Accessed 13 February 2017)

[29] Home - MyLeaf. <https://myleaf2.loccioni.com/beta/>, n.d. (Accessed 13 February 2017).

[30] L. Webster, J. Bradford, D. Sartor, J. Shonder, E. Atkin, S. Dunnivant, D. Frank, E. Franconi, D. Jump, S. Schiller, M. Stetz, B. Slattery, M\&V Guidelines: Measurement and Verification for Performance-Based Contracts Version 4.0, 2015.

[31] Italian Energy Efficiency Action Plan, 2014.

[32] G. Comodi, A. Giantomassi, M. Severini, S. Squartini, F. Ferracuti, A. Fonti, D. Nardi, M. Morodo, F. Polonara, Multi-apartment residential microgrid with electrical and thermal storage devices: experimental analysis and simulation of energy management strategies, Appl. Energy 137 (2014) 854-866, http:// dx.doi.org/10.1016/j.apenergy.2014.07.068.

[33] Loccioni Group. <http://www.loccioni.com/?lang=en/>, n.d. (Accessed 13 February 2017).

[34] Leaf Community | Loccioni Energy. <http://energy.loccioni.com/category/leafcommunity/?lang=en/>, n.d. (Accessed 13 February 2017). 
[35] Department of Meteorology - Climate of Cyprus. <http://www.moa.gov.cy/ $\mathrm{moa} / \mathrm{ms} / \mathrm{ms}$.nsf/DMLcyclimate_en/DMLcyclimate_en?OpenDocument/> n.d. (Accessed 6 March 2017)

[36] I. Renewable Energy Agency, Renewable Energy Roadmap for the Republic of Cyprus Summary for Policy Makers About Irena, 2015.

[37] Transition to Sustainable Buildings Strategies and Opportunities to 2050 OECD/IEA, Paris, 2013

[38] A. Eisentraut, A. Brown, Heating Without Global Warming Market Developments and Policy Considerations for Renewable Heat, n.d.

[39] D.S. Kim, C.A. Infante Ferreira, Solar refrigeration options - a state-of-the-art review, Int. J. Refrig. 31 (2008) 3-15, http://dx.doi.org/10.1016/j.ijrefrig.2007. 07.011.

[40] H.-M. Henning, Solar assisted air conditioning of buildings - an overview, Appl. Therm. Eng. 27 (2007) 1734-1749, http://dx.doi.org/10.1016/j. applthermaleng.2006.07.021.

[41] W. Saman, M. Krause, K. Vajen, Solar Cooling Technologies: Current Status and Recent Developments, n.d.

[42] A. Neuhaeuser, A. Sauerborn, W. Platzer, Polygeneration Using Concentrated Solar Thermal Power, 2009, www.ise.fraunhofer.de. (Accessed 9 December 2016).

[43] S. Vasta, A. Frazzica, A. Freni, L. Venezia, A. Buscemi, F. Paredes, F.M. Montagnino, A concentrating - based solar cooling system for agri-food industry, in: Acts of 5th International Conference Solar Air-Conditioning, Bad Krozingen, 2013.

[44] T.L. Freeman, J.W. Mitchell, T.E. Audit, Performance of combined solar-heat pump systems, Sol. Energy 22 (1979) 125-135, http://dx.doi.org/10.1016/ 0038-092X(79)90096-3.

[45] M. Quirante, L. Valenzuela, Dimensioning a small-sized PTC solar field for heating and cooling of a hotel in Almería (Spain), Energy Procedia 30 (2012) 967-973, http://dx.doi.org/10.1016/j.egypro.2012.11.109.

[46] F. Calise, A. Palombo, L. Vanoli, Maximization of primary energy savings of solar heating and cooling systems by transient simulations and computer design of experiments, Appl. Energy 87 (2010) 524-540, http://dx.doi.org/10 1016/j.apenergy.2009.08.033.
[47] M. Mazloumi, M. Naghashzadegan, K. Javaherdeh, Simulation of solar lithium bromide-water absorption cooling system with parabolic trough collector Energy Convers. Manag. 49 (2008) 2820-2832, http://dx.doi.org/10.1016/j. enconman.2008.03.014.

[48] K.F. Fong, T.T. Chow, C.K. Lee, Z. Lin, L.S. Chan, Comparative study of different solar cooling systems for buildings in subtropical city, Sol. Energy 84 (2010) 227-244, http://dx.doi.org/10.1016/j.solener.2009.11.002.

[49] N.S. Thakur, V. Mittal, K.S. Kasana, The study of solar absorption air-conditioning systems, J. Energy South. Afr. 16 (2005), @BULLET

[50] C. Papanicolas, M.A. Lange, N. Fylaktos, A. Montenon, G. Kalouris, N. Fintikakis, M. Fintikaki, D. Kolokotsa, K. Tsirbas, C. Pavlou, K. Vasilakopoulou, M. Santamouris, Design, construction and monitoring of a near-zero energy laboratory building in Cyprus, Adv. Build. Energy Res. 9 (2015) 140-150, http://dx.doi.org/10.1080/17512549.2015.1014837.

[51] P.A. Fokaides, C.N. Maxoulis, G.P. Panayiotou, M.K.-A. Neophytou, S.A. Kalogirou, Comparison between measured and calculated energy performance for dwellings in a summer dominant environment, Energy Build. 43 (2011) 3099-3105, http://dx.doi.org/10.1016/j.enbuild.2011.08.005.

[52] Fanos Karantonis, Energy Audit at the Cyprus Institute Novel Technologies Laboratory, Nicosia, 2014.

[53] NOAA Solar Position Calculator. <https://www.esrl.noaa.gov/gmd/grad/ solcalc/azel.html/>, n.d. (Accessed 6 March 2017).

[54] Meteonorm: Irradiation Data for Every Place on Earth. <http://www. meteonorm.com//>, n.d. (Accessed 6 March 2017).

[55] H. Müller-Steinhagen, Nicole Janotte, Siw Meiser, Dirk Krüger, Eckhard Lüpfert, Robert Pitz-Paal, Stephan Fischer, Quasi-dynamic analysis of thermal performance of parabolic trough collectors, SolarPACES (2009).

[56] S.A. Kalogirou, Solar thermal collectors and applications, Prog. Energy Combust. Sci. 30 (2004) 231-295, http://dx.doi.org/10.1016/j.pecs.2004.02. 001

[57] M.K. Theophilou, D. Serghides, Estimating the characteristics of the Urban Heat Island Effect in Nicosia, Cyprus, using multiyear urban and rural climatic data and analysis, Energy Build. 108 (2015) 137-144, http://dx.doi.org/10. 1016/j.enbuild.2015.08.034. 